The European Central Bank: Building a Shelter in a Storm

by

Dae Woong Kang, Princeton University

Nick Ligthart, College of Europe in Bruges, Belgium

Ashoka Mody, Princeton University

Griswold Center for Economic Policy Studies

Working Paper No. 248, December 2015 


\title{
The European Central Bank: Building a Shelter in a Storm
}

\author{
Dae Woong Kang, Nick Ligthart, and Ashoka Mody ${ }^{1}$
}

December 12, 2015

\begin{abstract}
As the financial crisis gathered momentum in 2007, the United States Federal Reserve brought its policy interest rate aggressively down from 51/4 percent in September 2007 to virtually zero by December 2008. In contrast, although facing the same economic and financial stress, the European Central Bank's first action was to raise its policy rate in July 2008. The ECB began lowering rates only in October 2008 once near global financial meltdown left it with no choice. Thereafter, the ECB lowered rates slowly, interrupted by more hikes in April and July 2011. We use the "abnormal" increase in stock prices - the rise in the stock price index that was not predicted by the trend in the previous 20 days - to measure the market's reaction to the announcement of the interest rate cuts. Stock markets responded favorably to the Fed interest rate cuts but, on average, they reacted negatively when the ECB cut its policy rate. The Fed's early and aggressive rate cuts established its intention to provide significant monetary stimulus. That helped renew market optimism, consistent with the earlier economic recovery. In contrast, the ECB started building its shelter only after the storm had started. Markets interpreted even the simulative ECB actions either as "too little, too late" or as signs of bad news. We conclude that by recognizing the extraordinary nature of the circumstances, the Fed's response not only achieved better economic outcomes but also enhanced its credibility. The ECB could have acted similarly and stayed true to its mandate. The poorer economic outcomes will damage the ECB's long-term credibility.
\end{abstract}

\footnotetext{
${ }^{1}$ Kang and Mody are at the Woodrow Wilson School, Princeton University. Ligthart, who recently graduated from Princeton University, is now with the College of Europe in Bruges, Belgium. For generous comments we are grateful to Yacine Ait-Sahalia, Michael Bordo, Iris Chan, Stijn Claessens, Henry Ergas, Antonio Fatas, Edward Hadas, Robert Hetzel, Patrick Honohan, Otmar Issing, Kevin O’Rourke, Graham McKee, Rick Mishkin, Ewan Rankin, Hans-Werner Sinn, Lars Svensson, JeanClaude Trichet, Emil Verner, Guntram Wolff, and seminar participants at the European Central Bank, Bruegel, and Princeton's EU Program.
} 


\section{Introduction}

Although the financial crisis originated in the United States in early 2007, it spread quickly to the eurozone. The shock to banks moved rapidly from the U.S. to the euro area, because banks were perceived as facing a common risk. $^{2}$ And probabilities of default and volatilities in credit markets rose together. ${ }^{3}$ The economies on both sides of the Atlantic experienced parallel and equal-sized declines in stock prices and GDP through 2008 and the first half of 2009 (Figure 1). Thus, although the crisis was viewed — especially in Europe — as mainly a U.S. problem, the eurozone felt virtually the same impact in the early stages of what was later called the "Great Recession."

Figure 1: Stock and GDP Price Movements

\section{(a) Stock Prices}

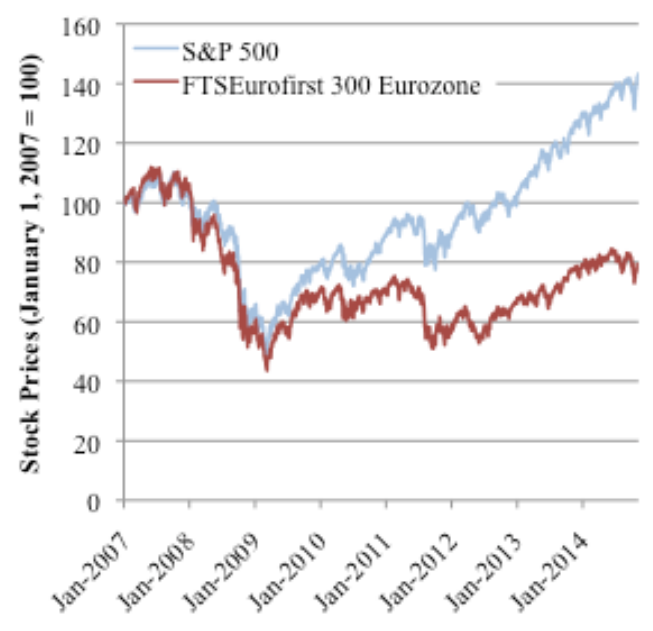

\section{(b) GDP}

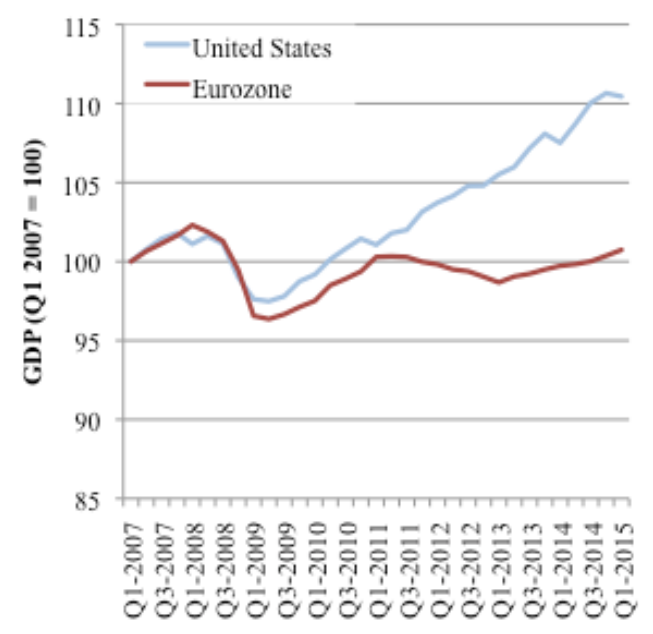

Note: Stock prices are normalized to equal 100 on January 1, 2007, and GDP is normalized to equal 100 in the first quarter of 2007.

Sources: For stock prices: (a) Federal Reserve Bank of St. Louis, "S\&P 500C (SP500)," available from: research.stlouisfed.org/fred2/series/SP500/downloaddata; and (b) DataStream, "FTSEUR1ST 300 EZ E PRICE INDEX; Code: FTEUEBL(PI)," Thomson Financial. For GDP, OECD Statistics "B1_GE: Gross domestic product - expenditure approach; LNBQRSA: Millions of national currency, chained volume estimates, national reference year, quarterly levels, seasonally adjusted," available from: stats.oecd.org.

${ }^{2}$ Eichengreen et al. (2012).

${ }^{3}$ BIS (2008, Chapter VI, Graph VI.2). Indeed, Hyun Shin (2012) has argued that European banks actively participated in creating the U.S. subprime bubble and required special support from U.S. authorities. 
Ironically, the recovery was much quicker in the U.S. than in the eurozone. By late-2011, U.S. stock prices and GDP were close to their pre-crisis levels. In contrast, these eurozone metrics were below their pre-crisis levels even in the first quarter of 2015. In the U.S., early, concerted, and proactive policy response helped renew investor confidence. Such improved sentiment, as George Akerlof and Robert Shiller have argued, is crucial to break the downward economic and financial spiral in a crisis and to sustain the recovery. ${ }^{4}$ Shiller has recently reemphasized the theme:

“... swift, effective intervention is needed in the face of financial collapse. We need to give free rein to fiscal and monetary authorities to take aggressive steps when financial turmoil turns into financial crisis. ${ }^{5}$

The U.S. pushed early and aggressively in the use of all policy instruments. In 2008-9, they imparted greater fiscal stimulus than in the euro area; the U.S. also, returned to austerity later, in 2011, rather than in 2010 as in the eurozone. ${ }^{6}$ More important was the active resolution of banking sector stress in the U.S.; the eurozone banking problems were allowed to fester. And throughout, U.S. monetary policy was much more aggressive.

In this paper, we focus on the stark difference in the speeds at which policy interest rates were reduced. In the U.S., the policy rate (the Fed Funds rate) was reduced from 51/4 percent in September 2007 to close to zero in December 2008 (Figure 2). ${ }^{7}$ At that point, the Fed also initiated the so-called quantitative easing program and began "forward guidance," which made public its intention to keep interest rates low "for some time." In the eurozone, the first reaction to the Great Recession was to its raise policy rate

\footnotetext{
${ }^{4}$ Akerlof and Shiller (2009).

5 Shiller (2015).

${ }^{6} \operatorname{Mody}(2015$, p. 2).

${ }^{7}$ The U.S. Federal Funds rate determines the rate at which banks lend to each other.
} 
(the main refinancing rate) in July $2008 .{ }^{8}$ After the Lehman Brothers' bankruptcy in

September 2008, the ECB had no choice but to join a coordinated rate reduction on

October 8. But then, the ECB's slow pace of rate reduction was interrupted by two more

hikes - in April and July 2011. Policy rates were brought to near-zero only in November 2013; quantitative easing began in a small way in September 2014 and was expanded in January 2015.

\section{Figure 2: Policy Rates: the U.S. Federal Reserve and the European Central Bank}

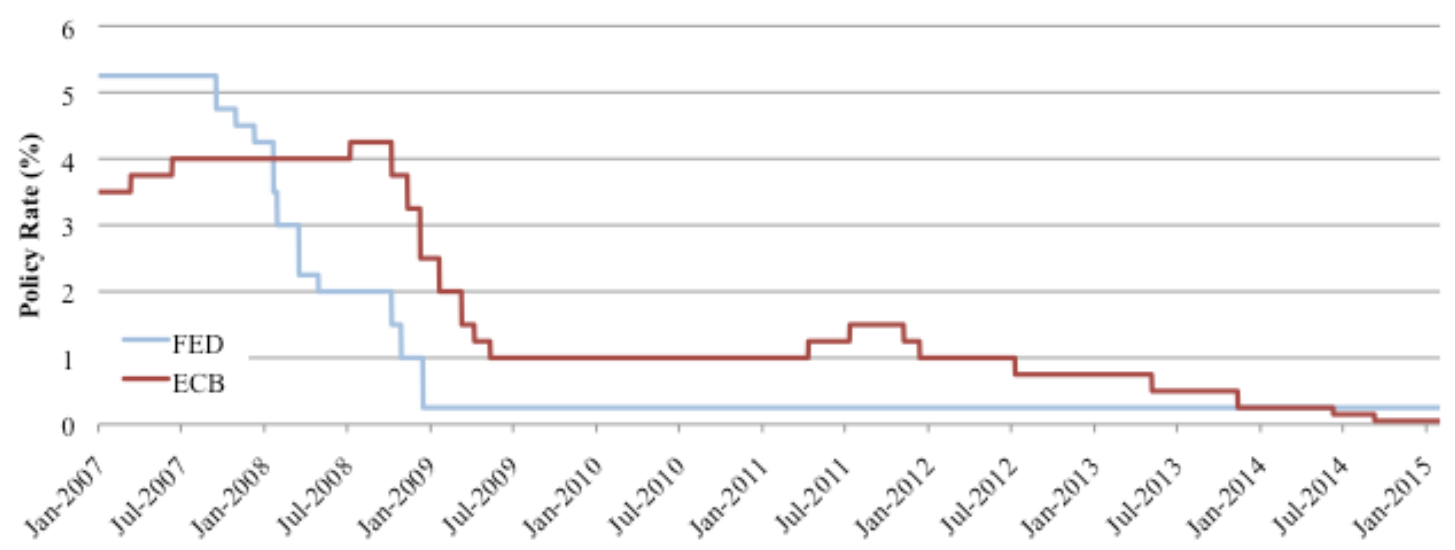

Sources: Federal Reserve Bank of New York, "Federal Funds Data Historical Search," www.newyorkfed.org. European Central Bank, History of all ECB open market operations, "Main Refinancing Operations," www.ecb.europa.eu.

Our empirical analysis confirms that by moving more rapidly — and with a clear focus on averting a catastrophic outcome - the Fed was also more effective in reviving confidence, essential for economic recovery. In contrast, the ECB's hesitant response sent

\footnotetext{
${ }^{8}$ The eurozone's main refinancing rate is the interest rate banks pay to borrow from the ECB. Normally, this rate also determines the euro overnight index average (EONIA), the rate at which banks lend to each other in the "unsecured" market. But because banks relied principally on the ECB for their funding through much of the crisis, there was little activity in banks' unsecured market and the EONIA was close to the much lower rate at which banks deposit money at the ECB (European Central Bank, 2010 and 2015b).
} 
mixed signals of its focus and intent and, therefore, did little to help revive the euro area economies.

To reach this conclusion, we use a mix of approaches. Ultimately the goal is to relate monetary policy decisions to growth and inflation outcomes. But tracing a link between any policy announcement (or even a set of these) to macroeconomic developments is difficult. Our approach offers, we believe, the most reasonable possibility of isolating the ECB's role during the crisis. We study the link between the policy intent accompanying the announcement and the change in sentiment that followed. The change in sentiment is inferred by the stock market's immediate reaction and the concurrent market commentary. We interpret this story in a framework that emphasizes macroeconomic risk management, with credibility achieved by matching words and deeds.

To examine the stock market's response to the announcement of interest rate cuts, we use an event-study methodology similar to that of Ait-Sahalia et al. (2012). We measure the "cumulative abnormal change" in stock prices on each trading day after the announcement. The "abnormal difference" is measured as the change in the stock price on that day minus the average daily change over the twenty days before the announcement. The presumption is that absent the announcement, stock prices would have continued to change at the pace of the past twenty days: hence, the abnormal change can be attributed to the policy announcement. Adding up the daily abnormal differences, the cumulative abnormal difference shows the post-announcement divergence in the stock price movement from the trend in the preceding twenty days. The results are summarized in Figure 3. The Fed, by cutting rates down to nearly zero by December 
2008, helped boost stock markets in 2007-8. For the slower-moving ECB, the market reaction was, on average, negative throughout.

Figure 3: Stock Market Reactions to the Reduction of Interest Rates

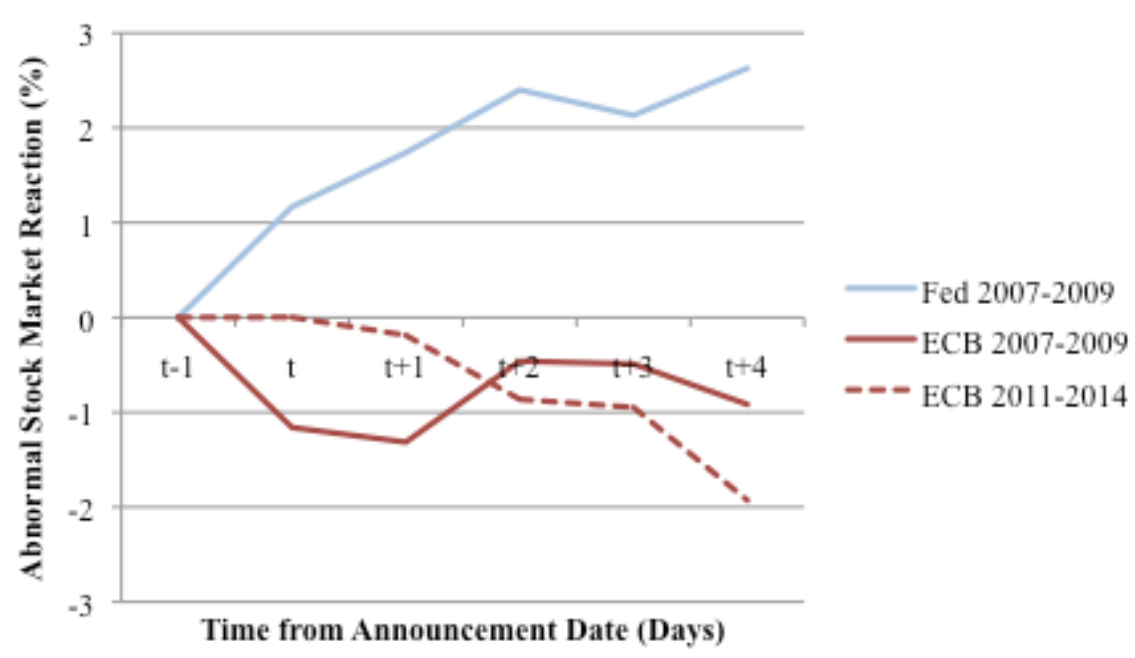

Note: In computing the average reaction for 2007-2009, we do not include the market reaction on October 8,2008 , as explained below. " $t-1$ " refers to the market closing stock price on the day before the announcement. The market reaction is measured as the abnormal difference starting with the market closing price on the day of the announcement ("t") and on the following four days. The abnormal difference is measured as the cumulative change relative to the change based on a continuation of the past 20-day trend.

Such event-study analyses, while customary, have clear limitations. The first concern is that the stock market's reaction is assessed within a small time window around the announcement. This is necessary to best isolate the announcement from other influences on stock prices. But, as a result, we cannot be sure if the effect observed in the narrow time window persisted beyond it. Consistent though with our findings around the announcements, the U.S. and euro area stock indices diverged, as seen in Figure 1. Second, stock price changes are admittedly an imperfect measure of our principal interest, which is in real economic change. During the Great Recession, however, as Figure 1 shows, stock price movements tracked well the relative differences in GDP performance. This comovement is consistent with the Akerlof-Shiller view that improved 
investor sentiment stems the fall in output and helps begin the recovery. In this context, a concern specific to the euro area could be that stock price movements do not reflect monetary policy decisions because firms rely more on banks than on market funding. But as in the United States, tighter euro area monetary policy in the pre-crisis years was followed by an adverse stock market reaction, as if anticipating slower economic activity. ${ }^{9}$

A final concern with the event-study methodology is that markets may have anticipated the announcement and so may already have made the necessary adjustments. This would presumably be more likely for the ECB because the Fed's earlier actions may have led markets to expect that the ECB would eventually act similarly. We report whether or not the announcement was expected - and also whether the rate cut was less or more than expected. And we narrate the market reaction immediately following the announcement. The unexpected announcements did trigger a stronger response than expected announcements in the U.S., but the anticipation of the announcements was not the primary influence on stock prices. We argue that even when anticipated, announcements provided new information about the central bank's commitment (or the lack of it).

The Fed's early and aggressive moves conveyed a willingness to counter the risk of prolonged financial and economic distress. Acting preemptively, the Fed was perceived as leading the markets. In contrast, the ECB, preoccupied with inflation risk, responded grudgingly. As such, markets were never sure what the ECB was trying to

\footnotetext{
${ }^{9}$ Bohl, Siklos and Sondermann (2008).
} 
achieve, and often viewed the rate cuts as harbingers of bad news or as inadequate to the task at hand.

The central banks' differing mandates were not the reason for the differences in their response to the Great Recession. True, the Fed has a clear dual mandate to support employment (and output) and maintain price stability. ${ }^{10}$ But the ECB — despite its formal focus on price stability — has also, in the past, acted as if it had a dual mandate. Indeed, as Lars Svensson has pointed out, it could not be otherwise. The ECB's focus on "mediumterm" price stability (over a two-year horizon) implies that, like other central banks, it does not seek to bring inflation down instantly since attempting to do so would cause an unreasonable drop in output. ${ }^{11}$ The result, Svensson argues, is that ECB's stated objective is indistinguishable from that of central banks with dual mandates. ${ }^{12}$ Not surprisingly, therefore, John Taylor found, that between 2000 and 2006, the ECB and the Fed both responded to output shortfalls and inflationary pressures. ${ }^{13}$ Fernanda Nechio reached a similar conclusion. ${ }^{14}$

The difference between the Fed and the ECB during the Great Recession was not due to their differing mandates but was due rather to the evaluation of risks associated with the crisis. During the Great Recession, the Fed went beyond a narrow interpretation of its "dual mandate." It operated, as Alan Blinder says, on the "dark" view that a huge

\footnotetext{
${ }^{10}$ Steelman (2011).

${ }^{11}$ Svensson (1999, pp. 83, 96, and 107).

${ }^{12}$ Svensson (2013, p. 33, footnote 2) makes the same point in a different way. A primary mandate of price stability requires that the inflation target gets priority over a medium-term horizon (i.e., the mean inflation rate must be close to the target rate without regard to an employment or output goal). However, short-run macroeconomic fluctuations (the variance) must also be managed, which requires paying attention also to economic activity.

${ }^{13}$ Taylor (2010).

${ }^{14}$ Nechio (2011).
} 
loss of wealth could tip the economy and financial system into free fall. ${ }^{15}$ The priority was to prevent or manage that risk. ${ }^{16}$ The Fed's monetary policy was, therefore, more aggressive than if it had followed its previous norms. It played down inflation risk in 2007-8 and made, instead, the judgment that the risk of prolonged economic contraction required special attention. To that end, the Fed ramped up its provision of market liquidity to facilitate financial transactions just as the ECB did, but the Fed also brought down interests rates quickly. And once the policy interest rate could not be lowered further, easy monetary policy was maintained through quantitative easing and through "forward guidance." These "nonconventional" measures were bolstered in 2010 to fend off the risk of price deflation even after the haltingly economic recovery had begun.

In contrast, the ECB interpreted the onset of the Great Recession as a primarily a liquidity crisis. ${ }^{17}$ In other words, the ECB took the view that a temporary scare had caused banks to hoard cash and thus restrict lending to other banks. These financial market disruptions, the ECB determined, mainly required additional liquidity provision. ${ }^{18}$ The ECB's interest rate policy continued to assign relative weights to output and inflation objectives as in the past. ${ }^{19}$ And the fear that commodity price inflation would feed into wage inflation, led to hikes in the policy rate in July 2008 and in April and July 2011.

The essential difference between the Fed and the ECB, therefore, boiled down not to their mandates but to how each institution viewed the likely evolution of the economy. The difference manifested itself, in part, in the ECB's focus on commodity price

\footnotetext{
15 Blinder (2013, p. 94).

${ }^{16}$ See BIS (2008, p. 64) for an early description of the Fed's actions in these terms.

${ }^{17}$ Blinder (2013, p. 94).

18 Stark (2008).

${ }^{19}$ BIS (2008, Graph IV.3, p. 63).
} 
inflation, which the Fed largely ignored. Commodity prices should have been expected to naturally come down in a weakening economy and, thus, not viewed as a threat to the ECB's goal of less-than-but-close-to 2 percent. ${ }^{20}$ While it overemphasized the risk of inflation, the ECB dealt with the deepening financial crisis mainly by easier provision of funds to banks and through other efforts to repair financial intermediation. These initiatives were clearly important to prevent a financial meltdown but were insufficient to induce more lending and stimulate economic growth. ${ }^{21}$ In Hetzel's words, the financial intermediation operations did not "put money into the pockets of people." 22 The Fed's more active and preemptive monetary stimulus - interest rate cuts and quantitative easing — helped counter the risk that loss of confidence, financial stress, and demand contraction would feed on each other.

The ECB also rejected a risk-management approach in 2013-14, when the euro area clearly began to slide towards deflation. While interest rates were gradually lowered, the ECB followed rather than anticipated the deceleration in inflation. Ironically, the ECB concluded that deflationary tendencies would be temporary because they were caused by falling commodity prices. Thus, ECB acted asymmetrically: rising commodity prices in 2007-8 were expected to feed persistent inflation but falling commodity prices after 2011 were expected to reverse course.

Thus, coming on top of fiscal austerity and lingering banking problems, the ECB's hesitant—and, at times, misguided—monetary policy prolonged the euro area's woes. Despite its rear-guard action, the ECB will be associated with the legacy of a weak

\footnotetext{
${ }^{20}$ Hetzel (2014).

${ }^{21}$ For this distinction between the central bank's function in stabilizing financial intermediation and for example, Hetzel (2012, chapter 14).

22 Robert Hetzel in a personal communication, December 23, 2014.
} 
recovery and more entrenched deflationary tendencies. This episode adds to the mounting evidence that policy delays in stimulating economic recovery have permanent consequences. $^{23}$

We conclude also that the Fed gained credibility even though it appeared to temporarily suspend its commitment to price stability. Managing the immediate and overriding risk was appropriate for the extraordinary circumstance of the Great Recession. Michael Bordo and Finn Kydland have argued that setting aside a policy rule to deal with the immediate contingency is consistent with commitment to long-term goals. ${ }^{24}$ As Blinder has emphasized, central bank credibility is not primarily associated with reinforcing inflation-fighting credentials, but rather requires that words be matched with deeds. ${ }^{25}$ The Fed read the crisis well and appropriately adapted its words and deeds.

In the rest of this paper, we first discuss the global crisis of 2007-9 and then the following years of deflationary risk. In each phase, we first describe the policy thought process at the two central banks. This is followed by the event study analysis to assess the market's response to the policy actions. Finally, a narrative of market commentary helps interpret the market's response. In a final section, we discuss what this episode has taught us about central bank credibility.

\section{The Global Crisis, 2007-2009}

Through the first half of 2007, the Fed and the ECB were both encouraged that the economy had slowed only modestly. Both were instead concerned that the commodity

\footnotetext{
${ }^{23}$ Fatas and Summers (2015) and Blanchard, Cerutti, and Summers (2015).

${ }^{24}$ Bordo and Kydland (1995).

${ }^{25}$ Blinder (2000 and 2012).
} 
price boom had persisted and was fueling inflation despite the fading economic boom. And while they were both worried about financial stability, neither saw an upheaval coming.

In May 2007, Fed Chairman Ben Bernanke insisted that the financial crisis would remain restricted to the so-called "subprime" sector: "[...] we believe," he said, "the effect of the troubles in the subprime sector on the broader housing market will likely be limited, and we do not expect significant spillovers from the subprime market to the rest of the economy or to the financial system." ${ }^{26}$ Across the Atlantic, with no evident financial stability concerns, the ECB's mid-June decision to raise its policy rate was not controversial. The OECD's Chief Economist spoke for many when he said that monetary authorities should "err on the side of tightness." 27

By early August, the financial rumbles had grown in the United States. The members on the Federal Open Market Committee (FOMC) — the Federal Reserve's rate setting body — were concerned that inflation was not letting up, but neither was the gathering financial crisis. At their August 7 meeting, the question for them was whether to raise the policy rate to fight inflation or to lower it to counter a possible economic slowdown due to continuing financial dislocations. The members compromised by keeping the rate unchanged. Blinder - a former Vice Chairman of the Board of Governors of the Federal Reserve System-writes: "Many Fed watchers blinked in disbelief. What were those guys thinking?"28

\footnotetext{
${ }^{26}$ Bernanke (2007).

${ }^{27}$ Cotis (2007).

${ }^{28}$ Blinder (2013, p. 92).
} 
On the morning of August 9, the French bank BNP Paribas refused to let customers withdraw their money from three funds with exposure to US subprime mortgages. ${ }^{29}$ That announcement by a major European bank triggered a transformation of the crisis. Banks immediately started worrying that lending to another bank for even a month may not be safe. This threatened to paralyze the nervous system of the international banking system. To alleviate the acute liquidity shortage, the ECB began later that same day to make cash freely available to banks. The Fed followed with a similar arrangement the next day. ${ }^{30}$

But there was, as yet, no active monetary stimulus to encourage businesses and households to keep spending. Blinder is appalled that the Fed waited until September 18 - “a full forty days after Paribas day"- -before lowering its policy interest rate by 50 basis points (100 basis points equal one percentage point). ${ }^{31}$ But from that point on, the balance at the Fed shifted slowly but decisively from concerns about inflation to worries about financial disruption. The FOMC members grew increasingly alarmed that the financial crisis may snowball. In January 2008, they lowered interest rates twice, on the $22^{\text {nd }}$ and on the $30^{\text {th }}$ by 75 and 50 basis points respectively. The rates were cut despite considerable disagreement in the committee on the direction of the U.S. economy. The

${ }^{29}$ BNP Paribas said that "evaporation" of market liquidity had made it impossible to value the funds and so redemptions could not be permitted. http://www.bloomberg.com/apps/news?pid=newsarchive\&sid=aW1wj5i.vyOg. See also BIS (2008, p. 95).

${ }^{30}$ See European Central Bank (2007) and Federal Reserve System (2007a). Over time, such operations to provide liquidity to banks and repair dislocations in specific financial markets were vastly expanded by both the ECB and the Fed. These efforts helped stabilize the global financial system. A more careful comparative analysis of such initiatives is required. However, even in this respect, the Fed was, if anything, more aggressive than the ECB. Moreover, European banks were structurally short of dollars and greatly benefited from the Fed's initiatives, including the Term Auction Facility set up in December 2007 and a series of swap arrangements with the ECB. In this paper, we focus on "active" monetary policy to stimulate demand, which is where the important difference between the ECB and the Fed lay.

${ }^{31}$ Blinder (2013, p. 93). 
transcripts of the FOMC meeting the January 29-30 reveal that some members were concerned with the risk of rising inflation while others—especially Janet Yellen, then President of the Federal Reserve Bank of San Francisco, and Chairman Bernankehighlighted the "downside risks" of a recession. ${ }^{32}$ They were concerned that an imminent recession might evolve into an unacceptably serious crisis.

The mortgage business kept unraveling and on March 14, the Fed began a rescue of Bear Stearns, which was bought two days later by J.P. Morgan. ${ }^{33}$ At the FOMC meeting on March 18, some members concluded the United States was in a full-blown financial crisis. Yellen described the situation as a "financial market implosion." 34 Frederic (Rick) Mishkin said: "[...] the reality is that we are in the worst financial crisis that we've experienced in the post-World War II era." ${ }^{35}$ The Committee members took note of the data that continued to warn of medium-term inflationary risk. And some were concerned that the Fed's reputation for fighting inflation would be damaged if interest rates were lowered. But despite the diversity of views, the members recognized that the U.S. economy was at a very important crossroads. Ultimately, the debate was between either a 50 or 75 basis points cut, with the larger reduction winning to protect against further financial market disruption.

The inflation rate had continued to rise, from an annual rate of 2 percent at the start of 2008 to a 3 percent annual pace by April. Even so, at its April $30^{\text {th }}$ meeting, the Fed reduced the rate by another 50 basis points. Some FOMC members did feel that the rate cuts were being overdone. In their view, monetary policy was already

\footnotetext{
${ }^{32}$ Federal Reserve System (2008a).

${ }^{33}$ Appelbaum et al. (2014).

${ }^{34}$ Federal Reserve System (2008b).

${ }^{35}$ Federal Reserve System (2008b).
} 
"accommodative" - low enough to stimulate investment and consumption — and the risk was that inflation might get out of hand. Yellen, however, emphasized:

"Although the real federal funds rate is accommodative by any usual measure, [this] is a situation in which spreads have increased so much and credit availability has diminished so much that looking at the real federal funds rate is just a very misleading way of assessing the overall tightness of financial conditions." 36

Yellen argued that a lower policy rate would help revive employment without hurting the “attainment of price stability over the medium term." Her argument carried the day. Finally, at its June meeting, with inflation still on the rise, the FOMC did finally hold rates through the summer before resuming rapid rate cuts after the Lehman Brothers bankruptcy. Hetzel is critical of even the brief pause in the summer of 2008 as creating a contractionary force ${ }^{37}$ The contrast with the ECB is, however, striking.

At his press conferences through 2007 and much of 2008, President Jean-Claude Trichet emphasized that run-away inflation was the primary threat and, hence, the Governing Council was focused on whether and when to raise the policy rate. At the September 6, 2007 press conference, Trichet described the ECB's philosophy. When asked what weight the ongoing global financial turbulence was being given in the ECB's decision making, he explained that fighting inflation was twice blessed — not only was inflation countered but so was the risk of financial instability. "The anchoring of inflation expectations," Trichet said, "is all the more important in a period of volatility of financial markets, $[\ldots]$ because it provides for all agents, investors, savers, in Europe and in the world a solid base for their medium-term and long-term decisions." 38 In the following

\footnotetext{
${ }^{36}$ Federal Reserve System (2008c).

${ }^{37}$ Hetzel (2009).

${ }^{38}$ Trichet and Papademos (2007b).
} 
months, Trichet stuck to this theme even as the Fed aggressively cut its policy rate.

In November 2007, a journalist asked Trichet whether "another large central bank is doing [things] differently" was creating confusion in the global financial markets. ${ }^{39}$

Trichet responded at some length:

"With regard to your subtle last question, I have no advice for other central banks! I have noted since the beginning of the period of "turbulences" that we were all in different economies with various characteristics and with various instruments at our disposal, taking into account our own histories and our own structures. I take it that what has been done has been responsible and I think we could certainly prove that we - each of us, in our own environment - probably did what was required by the situation. In the Governing Council, we will continue to consider that we have a major responsibility [...] to be credible - particularly in the eyes of our fellow citizens - in the delivery of price stability over the medium term." 40

Underlying Trichet's response was the implication that the Fed and the ECB were responding to different economic conditions. While the Fed was preoccupied with financial disruption and the risk it may snowball, Trichet remarked that the ECB had "observed a progressive appeasement of tensions in the money market ...."41 Again, in January 2008, Trichet emphasized that the indicators "generally remain at levels that continue to point to ongoing growth." 42 He restated that the greater concern was further rise in inflation, and while the Governing Council had held off from raising rates, it maintained a "tightening bias."

On February 7-after the Fed had reduced its policy rate by 125 basis points in January - a reporter again asked: “... do you interpret this [the Fed's steady interest rate cuts] as an effort to stop an economic contraction that is already underway or highly

\footnotetext{
39 Trichet and Papademos (2007d).

40 Trichet and Papademos (2007d).

41 Trichet and Papademos (2007d).

42 Trichet and Papademos (2008a).
} 
proactive risk management ...?"43 The question was a relevant one. The Fed was busy slashing its policy rate even though the U.S. growth projections looked no worse than those of the euro areal. ${ }^{44}$ Trichet repeated that each central bank needed to consider the specific features of its economy but, in the final analysis, both the Fed and the ECB had a primary focus on maintaining price stability. Trichet did concede that the economic slowdown in the United States would hurt euro area exports; he maintained, however, that domestic and foreign demand would "support ongoing growth." 45 He emphasized that corporate profitability had been "sustained" and that unemployment rates had "fallen to levels not seen for 25 years." 46 Once again, the Governing Council was more concerned about taming inflation.

After the Bear Stearns rescue in mid-March 2008, the ECB took note that "the level of uncertainty resulting from the turmoil in financial markets remains unusually high and tensions may last longer than initially expected." ${ }^{47}$ But this had little influence on the policy decision. Inflation continued to dominate the ECB's thinking. Governing Council Member and the ECB's Chief Economist insisted:

"The best contribution the ECB can make to foster confidence in the current situation is to continue to firmly anchor medium to long-term inflation expectations in the euro area by keeping its policy uncompromisingly geared to pursuing price stability. Adopting a more activist policy stance in the current situation, as some outside observers recommend, would only exacerbate uncertainty without helping to resolve the causes of the turbulences, which are outside the realm of monetary policy." 48

\footnotetext{
43 Trichet and Papademos (2008b).

${ }^{44}$ In January 2008, the International Monetary Fund projected that the U.S. and euro area would both grow their GDP by about $1 \frac{1}{2}$ percent in 2008; both forecasts has been lowered by about $1 / 2$ percentage point since October 2007. http://www.imf.org/external/pubs/ft/weo/2008/update/01/.

45 Trichet and Papademos (2008b).

46 Trichet and Papademos (2008b).

47 Trichet and Papademos (2008c).

${ }^{48}$ Stark (2008).
} 
In May, Trichet said that the Governing Council was unanimous in not easing monetary policy and in June he reported that the possibility of raising the interest rate had been discussed before deciding to leave it unchanged.

The glaring policy difference between the Fed and the ECB unfolded despite virtually identical inflation rates in the U.S. and in the euro area. The Fed, as we have seen above, made the judgment that prolonged recession was the greater risk. The ECB's management feared that inflation would become "entrenched": as prices rose, people would come to believe that prices were set to rise further, which would increase the demand for higher wages and render the expectation of higher inflation self-fulfilling. ${ }^{49}$ But this fear was unfounded, as even the hyper-ventilating French President Nicolas Sarkozy understood. In late June, he said:

"Inflation today is due to the explosion in commodity prices. You cannot tell me that in order to fight against inflation you must raise interest rates. You can double, triple interest rates and that will not decrease the price of a barrel of Brent." 50

Instead, Sarkozy warned, raising interest rate could choke the economy. ${ }^{51}$ The Spanish Prime Minister José Luis Rodriguez Zapatero made similar remarks.

Nevertheless, the widely anticipated rate increase by 25 basis points came on July 3. At the press conference, Trichet said the measure was intended to control inflation, which had soared to 4 percent, and wage pressures had also increased. ${ }^{52}$ Critics were concerned that the rate hike coming on top of the economic drag from rising commodity prices would further dampen growth, and euro area stock prices had fallen in

\footnotetext{
49 Trichet and Papademos (2008d).

${ }^{50}$ Wiesmann (2008).

${ }^{51}$ Hetzel (2014) later reached the same conclusion on the basis of a more scholarly analysis.

52 Bloomberg Businessweek (2008) and Gow (2008).
} 
anticipation. ${ }^{53}$ Trichet's tone did soften during the press conference, and observers, who had feared that this might be the start of a series of hikes, interpreted Trichet's comments to imply that another hike was unlikely soon. Markets rallied. ${ }^{54}$

The Lehman bankruptcy on September 15 threatened to tear apart the network of global commerce and finance. On October 8, the major central banks coordinated a rate cut of 50 basis points. This was the ECB's first rate reduction since the start of the Great Recession. Recall that Blinder was dismayed that the Fed had waited "a full forty days" before reducing its policy rate on September 18, 2007. Reporting the date of the ECB's first rate cut-October 8, 2008-Blinder exclaimed, "yes, that is 2008 not 2007." ${ }^{.55}$ With a global financial catastrophe looming, the ECB could not stay out of the internationally coordinated rate cut.

But the Fed-ECB differences continued. The Fed pushed its policy rate rapidly down to $0-0.25$ percent by December 2008, at which time it also initiated its first quantitative easing program and began "forward guidance" by promising to not to raise rates for a "some time." The ECB resumed its conservative stance. Despite the free fall in the euro area economy, the ECB gingerly lowered its policy rate down to 1 percent on May 13, 2009.

To assess if these policy differences were relevant to financial sentiment and, by implication, to economic performance, we compare the stock market response to lowering of interest rates. For the U.S., we use S\&P 500 and for the eurozone, we use the "FTSEurofirst 300 Eurozone." The response to the announcement is measured by the

\footnotetext{
${ }^{53}$ Lander (2008) and Bloomberg Businessweek (2008).

${ }^{54}$ Atkins (2008a), Lander (2008), and Watts (2008).

${ }^{55}$ Blinder (2013, p. 94).
} 
"abnormal" change in the stock prices. This is the change in excess of the change that would have occurred if the daily change over the 20 days before the announcement had persisted. The closing price on the day before the policy announcement is the starting point, identified as date "t-1" in the analysis. Since the announcement is made mid-day, the first day on which the market responds is date "t." We track the response over the five days from "t" to " $t+4$." With continuous news flowing in, a period longer than this would not be appropriate since, by then, other influences would have set in. Figure 4 reports the findings with and without October 8, 2008, the date on which (as noted above) the rate was coordinated across major central banks.

Figure 4: Stock Market Reactions to Interest Rate Cuts, 2007-9

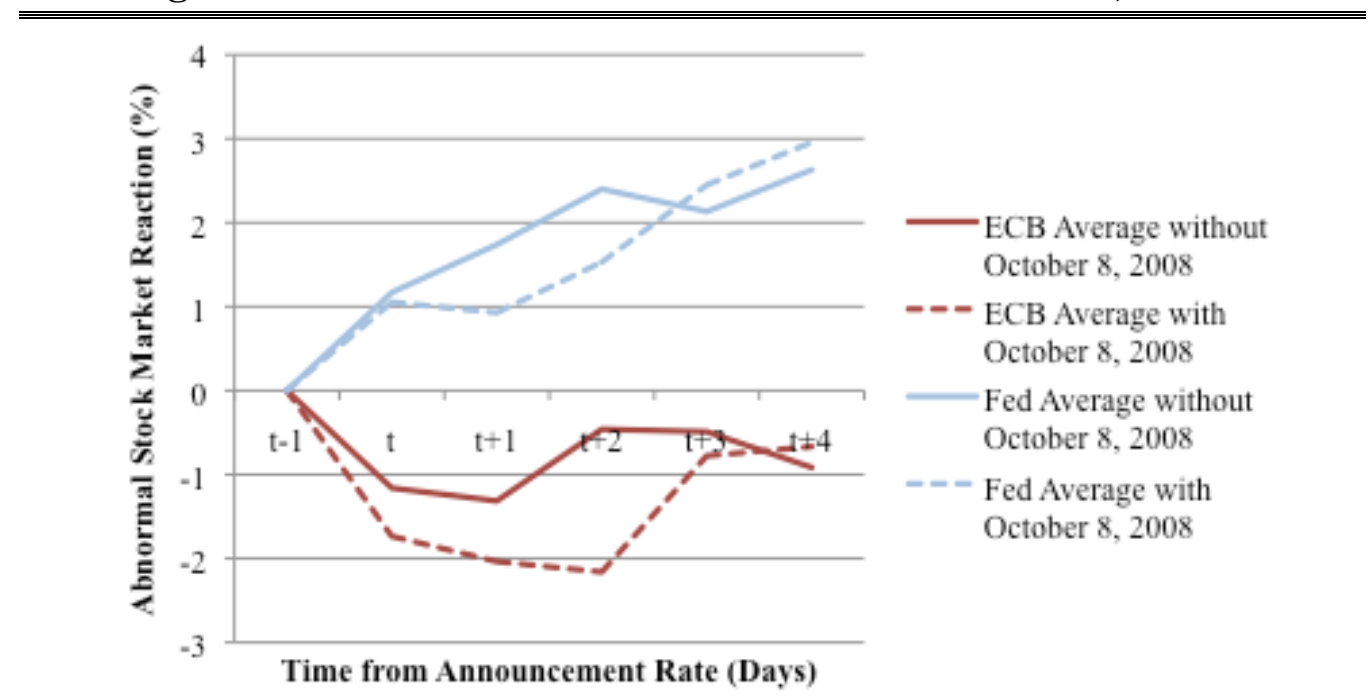

Note: We use the S\&P 500 for the U.S. and the FTSEurofirst 300 Eurozone for the euro area. "t-1" refers to the market closing stock price on the day before the announcement. The market reaction is measured as the abnormal difference starting with the market closing price on the day of the announcement (" $t$ ") and on the following four days. The abnormal difference is measured as the cumulative change relative to the change based on a continuation of the past 20-day trend. There were 10 rate reductions by the Fed and 7 by the ECB between September 2007 and May 2009. For the Fed, 8 of the 10 cuts had a positive outcome, if we consider the average of $3^{\text {rd }}$ to $5^{\text {th }}$ day and 7 of the 10 had a positive outcome if we stop on the $4^{\text {th }}$ day (December 16, 2008 is the one that differs); for the ECB, 3 of the 7 cuts had a positive outcome if we consider the average of $3^{\text {rd }}$ to $5^{\text {th }}$ day, and 4 out of 7 had a positive outcome if we consider only the $4^{\text {th }}$ day (since for the October 8 cut, the market recovered to a small positive outcome after a sharp initial fall). 
With or without the October 8 announcement, Figures 4 confirm the more positive response to the Fed. And although including October 8 in the analysis strengthens the Fed's advantage over the ECB, in the rest of this analysis we do not include that date. Stock prices fell sharply after the October 8 announcement in both the U.S. and the euro area although they recovered ground by the fourth day (Figure 5). Markets were still in a panic mode following the Lehman bankruptcy, and no policy action seemed sufficient. The extreme market volatility during those days cannot reasonably be associated with the rate cut.

Figure 5: October 8, 2008 rate cuts

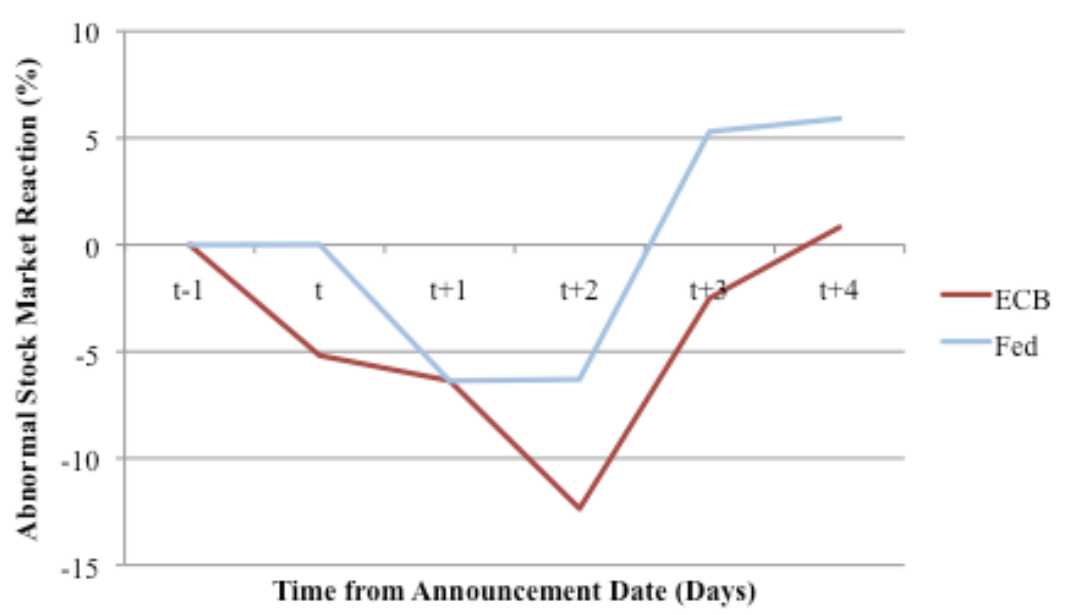

Note: "t-1" refers to the market closing stock price on the day before the announcement. The market reaction is measured as the abnormal difference starting with the market closing price on the day of the announcement (" $t$ ") and on the following four days. The abnormal difference is measured as the cumulative change relative to the change based on a continuation of the past 20-day trend.

The announcements were almost always anticipated. We rely either on a survey of analysts, where available, or on news reports to assess if the policy action was expected. Other than October 8, only the Fed's January 22 rate cut was unexpected. The abnormal differences are, indeed, larger for the sole unexpected announcement (Figure 6). Note, 
however, that even the expected Fed announcements prompted a favorable market response, with abnormal differences rising to about 2 percent on the fourth day. For the $\mathrm{ECB}$, all 6 of the non-October 8 announcements were anticipated and the average abnormal differences for these were negative over the five-day window. Thus, the Fed did better when comparing just the expected announcements. The implication also is that the favorable response to the Fed was not because it surprised markets. Rather, the Fed's actions revealed its increasingly longer-term commitment to keeping interest rates low.

Figure 6: Expected and Unexpected Rate Cuts, 2007-2009

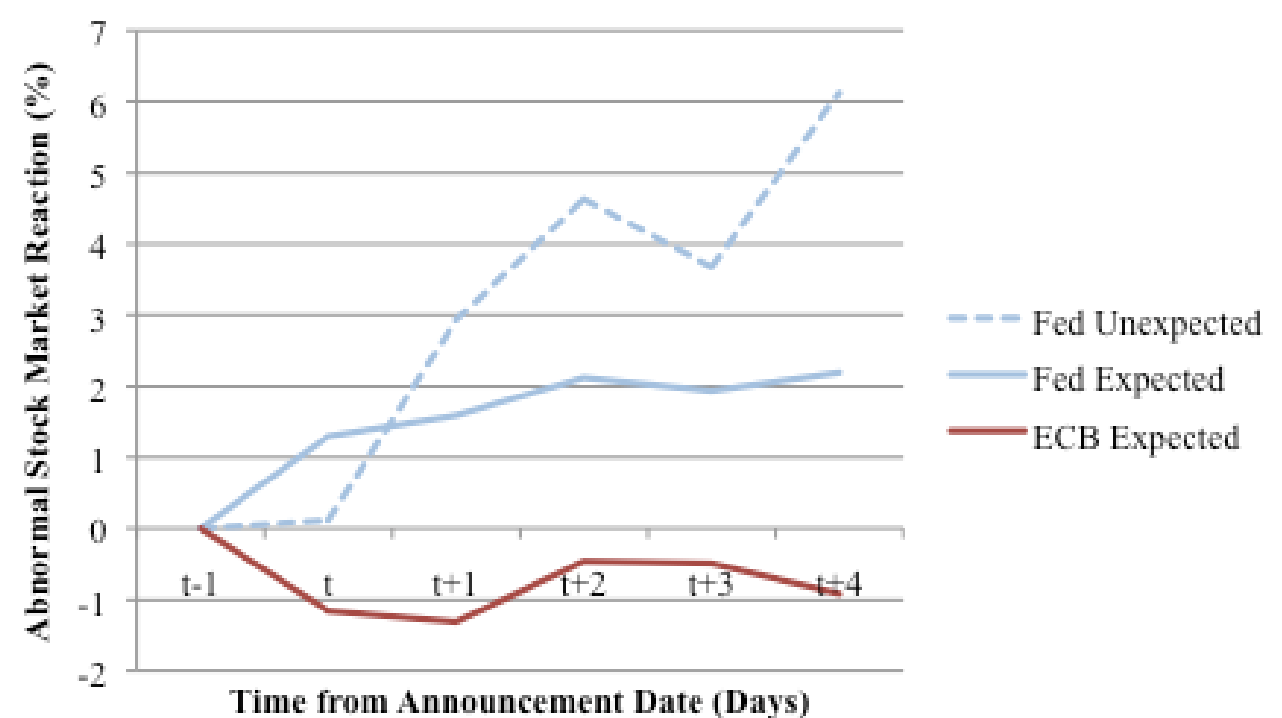

Note: Whether an announcement was expected or not, is judged by a survey of analysts, where available, and by reports in news articles in case no surveys are available. If markets correctly anticipated a cut, but not its size, we classified the cut as expected. As explained in the text, we do not consider October 8, 2008. Of the remaining announcements, one of the Fed announcements was unexpected (January 22, 2008) and 8 of the Fed announcements were expected, whereas all of the ECB's 6 cuts were expected. " $t-1$ " refers to the market closing stock price on the day before the announcement. The abnormal difference is measured as the cumulative change relative to the change based on a continuation of the past 20-day trend.

We see the news value of the longer-term commitment especially from the "aggressive" rate reductions. "Aggressive" announcements are defined as those for which the interest rate was reduced by at least 50 basis points. By this metric, for the Fed, 6 of 
the 9 non-October 8 rate cuts were aggressive. Figure 7 show that these were associated with an average abnormal increase over 4 percent on the $5^{\text {th }}$ day, and statistical tests say that the response was clearly positive. ${ }^{56}$ In contrast, the Fed's non-aggressive announcements were followed by a decrease of around 1 1 $\frac{1}{2}$ percent (although this was not statistically significant). The ECB gained little traction even with its aggressive rate cuts: the average response to these was negative, although not statistically different from zero.

Figure 7: Aggressive and Non-Aggressive Rate Cuts, 2007-2009

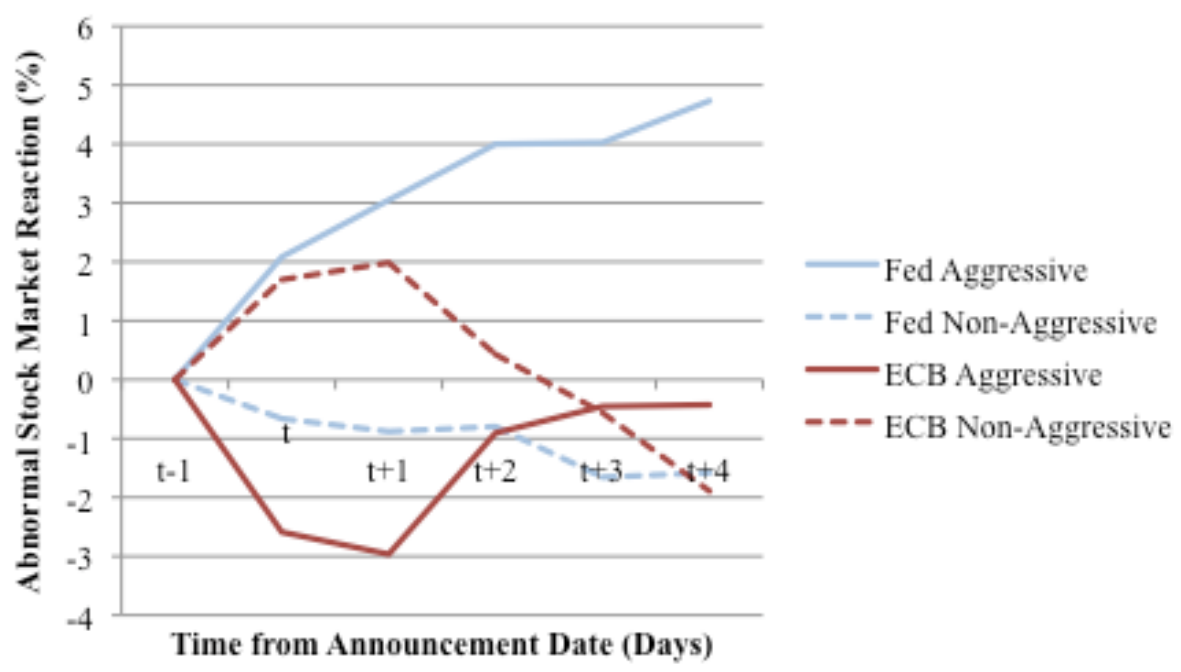

Note: Rate cuts were defined as aggressive if they were 50 basis points or larger, and non-aggressive otherwise. Once again, omitting October 8, 2008, 6 of the Fed's 9 rate cuts were "aggressive," and 4 of the ECB's 6 rate cuts were "aggressive." "t-1 " refers to the market closing stock price on the day before the announcement. The abnormal difference is measured as the cumulative change relative to the change based on a continuation of the past 20-day trend.

The Fed's early and aggressive actions represented not just a response to economic weakness but amounted to a change in strategy. Specifically, these actions engineered a departure from the Taylor's rule norms and, thereby, signaled that the Fed

\footnotetext{
${ }^{56}$ Welch's t-tests on the cumulative abnormal differences at $t+4$, as well as on the average of the cumulative abnormal differences from $\mathrm{t}+3$ through $\mathrm{t}+5$, show them to be statistically different from zero at the $10 \%$ and $5 \%$ levels, respectively. Bootstrap inference on the cumulative abnormal differences from $\mathrm{t}-1$ through $\mathrm{t}+5$ found these to be statistically different from zero at the $5 \%$ level.
} 
was not just responding to economic and financial news but was acting to preempt potentially more worrisome outcomes. While formal "forward guidance" came only with the December 16, 2008 rate cut, the actions up until then cumulated to establish a presumption that the Fed was creating a safety net. In effect, through its actions, the Fed was committing to a change in the conduct of monetary policy. ${ }^{57}$ Researchers at the Chicago Fed, indeed, find that even anticipated policy actions have positive stimulative effects if they come with the promise of further deviation from historical policy. ${ }^{58}$ Notice, on the occasions, when the rate cuts were not aggressive, the market responded negatively, presumably because of the concern that change in strategy was being abandoned. It is to the Fed's credit that it correctly read those messages and achieved greater consistency in its actions over time.

In contrast, by the time the ECB geared up, even its aggressive rate cuts were only playing catch up with the developments. The ECB's actions were a response to worse news, rather than with a change in the conduct of policy. ${ }^{59}$ In this sense, the norm of what constituted "aggressive" had changed: cuts that were regarded as aggressive when the Fed acted were now not ambitious enough to signal a new strategy. The ECB's actions came after the storm was already raging and were, for example, overshadowed by the even more aggressive cuts by the Bank of England and other central banks.

Two themes emerge from the market commentary. First, because this was uncharted territory, the Fed was determining new norms and guiding the markets. Second, while some market commentators did want to be reassured that the Fed would

\footnotetext{
${ }^{57}$ See Woodford (2012) on the distinction between policy response to news and a change in the policy. ${ }^{58}$ D'Amico and King (2015, pp. 2-3).

${ }^{59}$ Again, D'Amico and King (2015, p. 3) confirm that reactive policy hurts rather than helps.
} 
not neglect inflationary pressures, most sought the clarity and continuity of the crisisfighting message.

As noted, the Fed began the rate reduction cycle with a 50 basis points cut on September 18, 2007. Although market participants had expected a rate cut, they were surprised by its size. ${ }^{60}$ Most observers applauded, and stock markets surged. The Fed's announcement said it was acting to "forestall some of the adverse effects" from the financial disruptions, which was read as a signal that Fed would do what it could to limit the damage. ${ }^{61}$ One commentator remarked: "They said we're going to be a little bold and remove at least one source of uncertainty." 62

On October 31, 2007, the Fed cut rates by 25 basis points, as market participants had expected. ${ }^{63}$ Stock markets rose initially but then fell steadily back into negative territory. The ambiguity in the announcement was unwelcome. ${ }^{64}$ The Fed's concern about inflation implied that further easing could not be presumed. The reference in the Fed's statement to a "housing correction" drew particular comment. One analyst said: "My core view is that they really don't get it. This is not a housing correction. It is a massive, oncein-three-generation bursting of a housing bubble. It's a catastrophe, not a correction." 65

On December 11, 2007, the Fed again cut rates by an anticipated 25 basis points, although some had hoped for a 50 basis points cut. ${ }^{66}$ Stock markets again reacted negatively. The move was judged as too timid. Market participants had hoped for a more

\footnotetext{
${ }^{60}$ Felsenthal (2007) and Irwin (2007a).

${ }^{61}$ Federal Reserve System (2007b) and Irwin (2007a).

62 Felsenthal (2007) and Andrews and Peters (2007).

${ }^{63}$ La Monica (2007a).

${ }^{64}$ Andrews (2007).

65 Andrews (2007).

${ }^{66}$ La Monica (2007b).
} 
decisive cut, or at least a clear indication of future cuts. ${ }^{67}$ The Fed would not say whether it was more worried about inflation or economic growth, and only stated that "recent developments, including the deterioration of financial market conditions, have increased the uncertainty." ${ }^{68}$ Thus, although the Fed had started well in September, the next two actions in 2007 proved insufficiently ambitious.

On January 22, 2008 — a day after global stock prices had plummeted — the Fed cut interest rates by 75 basis points. This was the Fed's biggest cut since 1981-82. It came a week ahead of the Fed's next regularly scheduled meeting on January 29-30 and was, therefore, a complete surprise to market participants. ${ }^{69}$ The Fed said it "took this action in view of a weakening of the economic outlook and increasing downside risks to growth," and indicated it could lower rates further. ${ }^{70}$ Stock indices rose with relief. Some analysts did wonder if the Fed was merely panicking to global financial turbulence. ${ }^{71}$ But others saw it as catching up on ground lost in late-2007 and as a commitment to stay ahead of the markets. ${ }^{72}$ Former Fed official and Brandies University Professor Steve Cecchetti said: "The signal is that there is a new sheriff in town; when he see[s] changes in the economy that compromise medium-term stabilization objectives, he will do what needs to be done and do it right away."73

A week later, at its regular meeting on January 29-30, the Fed reduced the fed funds rate by another 50 basis points. ${ }^{74}$ Stock markets again reacted positively. On this

\footnotetext{
${ }^{67}$ Irwin (2007b).

${ }^{68}$ Federal Reserve System (2007c).

${ }^{69}$ BBC News (2008a).

${ }^{70}$ Federal Reserve System (2008e).

${ }^{71}$ BBC News (2008a).

${ }^{72}$ Guha (2008a), BBC News (2008a) and CNBC (2008).

${ }^{73}$ Cecchetti (2008).

${ }^{74}$ Seager (2008).
} 
occasion, the Fed noted that it expected inflation to moderate. ${ }^{75}$ The message by now was clear: the Fed would cut rates further. ${ }^{76}$ And while this worried some market participants, most now saw the Fed as "ahead of the curve."

At its next meeting on March 18, coming after the Bear Stearns bailout, the Fed cut rates again by 75 basis points. Some analysts had anticipated a 100 basis point cut, but the action satisfied many as an appropriate response to clearer evidence that a recession had begun. ${ }^{78}$ The market rally was also helped by relief that Goldman Sachs and Lehman Brothers had posted positive results. ${ }^{79}$

On April 30, the Fed held back with only a 25 basis points, in line with market expectations. ${ }^{80}$ The market commentary was lukewarm; even so the abnormal differences rose modestly. Market participants interpreted the small size of the cut and the relatively heavy emphasis on inflation in the accompanying statement as signs that the Fed would now take a wait-and-see approach. ${ }^{81}$ That interpretation proved correct since the Fed did pause for almost six months, at which point its hands were once again forced.

In the panic after the Lehman bankruptcy, there were no norms. On October 8, a 50 basis point reduction was coordinated with five other central banks, including the ECB and the Bank of England. ${ }^{82}$ Stock markets reacted very negatively initially, dropping by more than 6 percent on the second day after the announcement. Markets worried if

\footnotetext{
${ }^{75}$ Federal Reserve System (2008f).

${ }^{76}$ Isidore (2008a).

${ }^{77}$ Isidore (2008a).

${ }^{78}$ Isidore (2008b) and Andrews (2008).

${ }^{79}$ Guerrera \& White (2008) and Guha (2008b).

${ }^{80}$ NPR (2008a).

${ }^{81}$ Barr (2008).

82 Dougherty and Andrews (2008) and Isidore (2008a).
} 
central banks had the capacity to contain the spreading global turmoil. ${ }^{83}$ The U.S. markets did recover by the $4^{\text {th }}$ day, but it is unclear if that was because of the rate cut.

Three weeks later at a regular meeting on October 29, 2008, the Fed again cut rates by 50 basis points, as expected by market participants ${ }^{84}$ Explaining its decision, the Fed stated, “[...] the pace of economic activity appears to have slowed markedly, owing importantly to a decline in consumer expenditures." 85 Stock markets reacted positively. The Fed appeared to regain the market's confidence that it was back in-charge, and observers interpreted the Fed's accompanying statement as promising further monetary easing. ${ }^{86}$

Finally on December 16, 2008, the Fed slashed rates by 75 basis points down to 0-0.25 percent, which was a larger cut than the 50 basis points that markets had anticipated. ${ }^{87}$ With no more room to cut rates, the Fed announced its first quantitative easing program even as it said that "weak economic conditions are likely to warrant exceptionally low levels of the federal funds rate for some time." ${ }^{88}$ Bloomberg Businessweek commented: "It's a measure of the severity of the financial crisis that there were no dissenters from the Fed vote. Even inflation hawks such as Philadelphia Fed President Charles Plosser and Dallas Fed President Richard Fisher voted 'yes' on the measures." ${ }^{89}$ Market observers were reassured that the Fed was not about to run out of options. ${ }^{90}$ And the "unusually strong" message left little doubt that countering the

\footnotetext{
${ }^{83}$ Isidore (2008a).

${ }^{84}$ Isidore (2008b).

${ }^{85}$ Federal Reserve System (2008g).

${ }^{86}$ Ydstie (2008) and NPR (2008b).

${ }^{87}$ Coy (2008).

${ }^{88}$ Federal Reserve System (2008h).

${ }^{89}$ Coy (2008).

${ }^{90}$ Elliott and Seager (2008).
} 
economic downturn would receive priority over fighting inflation. ${ }^{91}$ Stock markets gained initially but these tapered by the $3^{\text {rd }}$ and, especially $4^{\text {th }}$ day after the announcement.

Meanwhile, the ECB's first rate cut on October 8 was off an inauspicious start. Analysts noted that the coordinated action had, "failed to calm gyrating markets [...] amid the growing realization that a serious and prolonged recession [would] be difficult to avoid." ${ }^{92}$ Then, the markets correctly anticipated the ECB's November 6 cut of 50 basis points, although a "stunning" 150 basis point cut by the Bank of England earlier that day had stoked expectations that the ECB would be more aggressive. ${ }^{93}$ Abnormal differences turned negative following the announcement, falling to almost negative 11 percent by the fourth day after. A commentator remarked: "The prospects for the eurozone avoiding recession now look virtually non-existent, and the ECB will be challenged to change its relatively conservative approach quickly to boost prospects across the continent, before a bad situation gets decidedly worse." ${ }^{94}$ Despite this feedback, the ECB remained cautious. Executive Board Member Bini Smaghi said: “The present crisis is partially due to interest rates that remained at low levels for too long. [...] rates were lowered too much in order to stimulate growth. We need to avoid repeating the same mistakes." 95 Trichet emphasized the risk of a wage-price spiral in his November 2008 press conference.

On December 4, 2008, the ECB surprised markets with a bigger-than-expected 75 basis point rate cut, larger than any cut the ECB had made before. This helped. Stock

\footnotetext{
91 Andrews and Calmes (2008), Coy (2008).

92 Dougherty and Andrews (2008).

93 Trotta (2008), CBS News (2008).

${ }^{94}$ CBS News (2008).

${ }^{95}$ Vits (2008). Bini Smaghi was a frequent spokesman on the ECB's operating philosophy. As member of the 6-person Executive Board, which included the ECB President and Vice-President, he participated in managing the ECB's day-to-day business.
} 
markets rallied strongly. Even so, the commentary was generally skeptical. The rate cut was a reaction to bad economic news rather than a harbinger of a new approach. Some observers found the ECB cut tame, considering "horrific" economic data, and large concurrent rate cuts of 100, 150, and 175 basis point rate cuts by the Bank of England, Reserve Bank of New Zealand, and Sweden's central bank, respectively. ${ }^{96}$ Moreover, Trichet refused to hint at further easing. "I will say nothing about January," he said. ${ }^{97}$

On January 15, 2009, the ECB cut its policy rate by 50 basis points. The anxieties were deep and even the ECB's growth forecast from the previous month had been marked down. ${ }^{98}$ Some had hoped for a 75 basis points reduction, and the ECB's so-called Shadow Council had called for a 100 basis points cut. ${ }^{99}$ Instead, Trichet revealed that the Governing Council had considered no rate cut at all so as to avert the risk of falling into a "liquidity trap;" moreover, he offered no prospect of further rate reduction in February, saying the next "important" policy meeting would be the one in March. ${ }^{100}$ Thus, although the policy rate was reduced at that meeting, the tone was grudging. Analysts accused the ECB officials of "dragging their heels" and "being behind the curve."101 A currency strategist remarked, "Trichet is focused more on inflation, which is not really a concern in the eurozone. The bigger issue at hand is growth prospects." ${ }^{102}$ Abnormal stock price differences turned negative after the announcement, decreasing steadily to almost negative 4 percent by the $5^{\text {th }}$ day.

\footnotetext{
96 Strupczewski (2008).

97 Trichet and Papademos (2008f).

98 Suoninen (2009) and Gow (2009).

${ }^{99}$ Suoninen (2009) and Meier (2009). The Shadow Council is an unofficial panel of 15 prominent European economists, founded at the initiative of Germany's Handelsblatt newspaper. Every month, it reports the majority view of its members.

100 Atkins (2009a) and Trichet and Papademos (2009a).

101 Rooney (2009) and Gow (2009).

102 Rooney (2009).
} 
Before the next meeting on March 5, 2009 decision, an exasperated Thomas Mayer of Deutsche Bank called for a 100 basis points reduction, predicting that the ECB would settle for 75 basis points: "You suspect the ECB just wants to close its eyes to what's going on. That's not good for the economy." ${ }^{, 103}$ When, instead, the ECB reduced its policy rate by 50 basis points, a Goldman Sachs analyst not surprisingly reiterated: "The ECB remains vastly behind the curve."104 Another observer remarked, "We need action from their side. They really should be exhausting the traditional weapons of monetary policy ..."105 At his press conference, Trichet conceded that growth prospects had continued to weaken and that inflation rates were "now expected to remain well below $2 \%$ over 2009 and $2010 . " 106$ While he did indicate the possibility of more action, he held off on announcing anything concrete. The market reaction was mixed. After an initial fall, abnormal differences which clawed back to end in positive territory.

At the April 2, 2009, the ECB again disappointed markets. Instead of the anticipated 50 basis points cut, Trichet announced a reduction of only 25 basis points. ${ }^{107}$ Markets held up nevertheless, in part, because on April 1 world leaders had agreed on a \$1.1 trillion injection of financial aid into the global economy. ${ }^{108}$ The rate cut itself, however, was not well received. "It sends the signal," said one analyst, "that they don't mean business ...."109 Moreover, Trichet said the ECB would not announce non-standard

\footnotetext{
${ }^{103}$ Kennedy (2009).

${ }^{104}$ Kennedy (2009).

${ }^{105}$ Dougherty (2009).

106 Trichet and Papademos (2009b).

107 Thesing (2009a).

${ }^{108}$ Ljunggren and Wroughton (2009), Lander and Sanger (2009). Of the \$1.1 trillion, \$750 billion was meant to increase IMF resources, including $\$ 250$ billion for international reserve assets (Special Drawing Rights) meant to supplement countries' official reserves. Additionally, $\$ 250$ billion was allocated to support trade finance, and $\$ 100$ billion was allocated to support additional lending by multilateral development banks.

${ }^{109}$ BBC News (2009b).
} 
measures (additional liquidity or quantitative-easing style measures) until the following month. Instead, he asserted that "the ECB has the capacity to be nonstandard." 110 This frustrated some market participants. "You cannot buy time forever," said one observer. ${ }^{111}$

As widely expected, at its meeting on May 7, 2009, the ECB cut the policy rate by 25 basis points. It also announced that it would: (a) buy $€ 60$ billion in covered bonds to promote lending, (b) extend the maturity of its long-term refinancing operations by one year, and (c) make the European Investment Bank an eligible counterparty in moneymarket auctions. ${ }^{112}$ Abnormal differences fell steadily starting a day after the announcement, decreasing by 6 percent by the fourth day after the announcement. While some observers welcomed the broader package, others were worried that the "nonstandard" measures were a sign of bad news, and hence a "desperate bid to pull the eurozone's stricken economy out of recession."113 An analyst remarked: "The fact that the ECB felt compelled to take this wide-ranging action highlights the fact that the eurozone economy remains in serious trouble, despite some recent signs that the rate of economic decline is moderating." $" 114$

Altogether, between 2007 and 2009, the ECB achieved little traction with financial markets because the policy actions came well after the financial economic dislocations had become serious. And when they did come, the actions always appeared to be playing catch up.

\footnotetext{
${ }^{110}$ Atkins (2009b) and Saltmarsh (2009).

${ }^{111}$ Fraher (2009).

112 CNN Money (2009), Dougherty and Werdigier (2009), Randow and Meier (2009).

113 Hopkins (2009).

114 Hopkins (2009).
} 
Why did the Fed and the ECB act so differently? We know from the data that the economic and financial movements in the U.S. and the euro area were nearly identical between 2007 and 2009 (Figure 1 above showed that for GDP and stock market trends and Figure 8 below shows the same for inflation). The ECB position was based on three considerations: inflation risk was serious, lower interest rates would reward errant investors, and it was necessary to keep some powder dry for a true emergency. To be clear, these alternate perspectives were alive within the United States, indeed within the FOMC. The decision to not lower the policy rate at the August 7, 2007 meeting was based precisely on considerations that the ECB Governors would have found familiar and agreeable. ${ }^{115}$ And the Fed hesitated at times in the later months for those same reasons. ${ }^{116}$

So, one part of the difference between the Fed and the ECB was, ultimately, a matter of judgment. At the FOMC, the "doves"- those in favor of aggressive rate reductions - made their case well. A Wall Street Journal analysis compared the forecasts by individual FOMC members. ${ }^{117}$ The "doves" had the better forecasts on growth and inflation. The best forecasts were by Janet Yellen, who anticipated slower growth and milder inflation than her peers did. In contrast, the "hawks" underestimated the decline in growth and overestimated the inflation risk.

The balance at the Fed began to shift in favor of the "doves" in late August 2007 and was first reflected in the September 2007 rate cut. This shift in balance also changed the metric of decision making. While policy is normally guided by "baseline" forecasts, "downside risks" - the low probability outcomes — became increasingly more central to

\footnotetext{
${ }^{115}$ See Ip (2007) on the debate at the August 7 meeting as also in the weeks before the next meeting.

116 Obrien (2014) and Ip (2007).

${ }^{117}$ Hilsenrath and Peterson (2007).
} 
the determining the decisions at the Fed. The Fed could, therefore, stay ahead of the curve as the risks quickly became reality. The ECB's Governing Council did not make that shift. Thus, although living through the same macroeconomic developments, the ECB operated - as Blinder pointed out — within an economic and financial framework that treated the adverse developments as mainly temporary.

To be clear, the ECB was not alone in making the judgments it did. The BIS, for example, said in its June 2008 Annual Report, “... inflation is actually rising, while significantly slower growth remains only a possibility in many parts of the world. In general, this should imply a bias of global policy towards being much less accommodating." 118 When the incoming data repeatedly conflicted with this view, the ECB was left to acknowledge that things had turned out worse than the baseline anticipated (the "downside risks" had materialized). But with each such acknowledgement, reasons were identified to expect some relief and improvement (demand from emerging markets, for example, would mitigate the reach and severity of the crisis). ${ }^{119}$

The ECB position was bolstered by European rhetoric on U.S. economic ills. The U.S. was in crisis because of its incurable tendency to live beyond its means and because of its complex financial structures. European policymakers and leaders often referred (with great self-confidence and, indeed, condescension) to reckless Americans. ${ }^{120}$ Joaquim Almunia, the European commissioner for monetary affairs, said in January

\footnotetext{
${ }^{118}$ BIS (2008, p. 143).

119 Trichet and Papademos (2008b), Trichet and Papademos (2008c), Trichet and Papademos (2008e)

${ }^{120}$ See Barber (2008) for European politicians' characterization of America's economic problems. Among European commentators, Tigges (2007) and Buiter (2007) described the Fed's rate cuts in September and November 2007 as intended to appease financial markets. Buiter (2008) described the unscheduled January 22, 2008 rate cut as a sign of panic.
} 
2008, "[...] big imbalances have built up over the years in the US economy - a big current account deficit, a big fiscal deficit and a lack of savings." Almunia added that he was "not engaged in any criticism but these [US] imbalances are the root cause of the current turbulence." In contrast, he said, because the eurozone's positive current account, sound fiscal position, and plentiful savings, "we are well prepared to weather this situation." Echoing those remarks, Jean-Claude Juncker, who headed the group of eurozone finance ministers, said: "We have to be concerned, but a lot less than the Americans, on whom the deficiencies against which we have warned repeatedly are taking bitter revenge.” At the ECB, Jurgen Stark expressed similar views. ${ }^{121}$

Some American commentators also criticized the Fed for bailing out investors and for panicking. ${ }^{122}$ But while the U.S. critics remained marginal, the European portrayal of the Great Recession as an American problem being mishandled by Americans melded into the general European narrative and, thus, became their cognitive frame for interpreting U.S. policy actions.

Lars Svensson, formerly Deputy Governor of the Swedish Riksbank, has argued that the ECB's Governing Council is too large and the members of the Council are not adequately trained to deal with complex economic challenges. ${ }^{123}$ But it is also the case that member nations represented on the Governing Council had differing interests. While we do not know what views were expressed in the ECB's Governing Council, French President Nicolas Sarkozy repeatedly called on the ECB to do more for euro area growth; he and Italian Prime Minister Silvio Berlusconi demanded that the ECB "look beyond its

\footnotetext{
${ }^{121}$ Stark (2009).

${ }^{122}$ See, for example, Hanke (2007).

${ }^{123}$ Svensson (2002).
} 
mandate to combat inflation" and "help spur eurozone economic growth." ${ }^{24}$ Spanish Prime Minister Zapatero also favored a more growth-oriented ECB. ${ }^{125}$ The Spanish and French national press similarly called for more proactive monetary stimulus. ${ }^{126}$ In contrast, Axel Weber, Bundesbank President and a member of the ECB's Executive Board publicly spoke of the need for restraint in monetary stimulus. ${ }^{127}$ And at the height of the economic anxieties in January 2009, German Finance Minister Pier Steinbruck pushed back on Sarkozy's demands for a more activist ECB. ${ }^{128}$ While, in principle, Germany does not have a veto on the ECB's Governing Council, the net effect of the heterogeneity in national views was that the German perspective was able to hold back early reduction in interest rates.

In sum, optimistic rhetoric on economic prospects, the "Europe is different" view, and the German influence in policy decisions reinforced each other. These traits carried over in the next phase.

\section{The Euro Area's Inglorious Interlude: 2011}

The world economy bounced back in 2010 and, to some, the Great Recession seemed over. The IMF's October 2010 World Economic Outlook forecast that the world economy would grow at an average annual rate of $4 \frac{1}{2}$ percent over the next five years, close to the heady pace in the years before the crisis. The U.S. economy did achieve a modest recovery, although it repeatedly stumbled. In contrast, between 2011 and 2013, the euro area was the world's hot spot. Virtually all euro area countries fell in and out of

\footnotetext{
${ }^{124}$ Weisman (2008) and Di Leo and Celeste (2008).

125 Weisman (2008).

${ }^{126}$ Izraelewicz (2007) and El País (2008).

127 Shellock (2008).

${ }^{128}$ Marsh (2009).
} 
recession and those in the periphery remained under the perpetual threat of a crisis. It was in this phase that the U.S. clearly stepped ahead of the euro area, as Figure 1 showed.

The U.S. had largely dealt with its banking system problems by 2010: the most stressed banks had either been closed or adequately recapitalized. By comparison, the euro area had barely started dealing with its banks. The U.S. also had the advantage of a larger fiscal stimulus between 2007 and 2009 and had returned to austerity in 2011 rather than in 2010 as in the euro area. On top of the already much larger monetary stimulus, Bernanke made clear that the Fed was not yet done. ${ }^{129}$ Ken Wattret of BNP Paribas said it best: Bernanke's message focused on "what the Fed could still do;" the message from Trichet was "we have done all these measures and they appear to be working."130

Now a new challenge appeared. Inflation rates had picked up with the spurt in commodity prices that accompanied the brief global economic bounce back in 2010 . Once again, the U.S. and euro area authorities faced virtually identical inflation data (Figure 8a). ${ }^{131}$ After the sharp fall in 2009, inflation rose to above a 2 percent annual rate in March 2011 and kept rising for the rest of the year. The so-called "core" inflation, which strips out the volatile food and energy prices, was rising in parallel but was well below 2 percent level (Figure $8 b$ ). Most economists consider it appropriate to focus on core inflation since food and energy price movements are expected to reverse. The ECB, however, pays attention to headline inflation, presumably, because the volatile component of headline inflation can feed into higher wage demands and hence become

\footnotetext{
${ }^{129}$ Bernanke (2010).

${ }^{130}$ Kennedy and Lanman (2010).

${ }^{131}$ We use the 12-month average of monthly year-on-year inflation rates.
} 
entrenched. But an uncontrolled wage-price spiral was an unreasonable worry with unemployment still rising.

Figure 8: Headline inflation and core inflation for the US and Eurozone

(a) Headline inflation

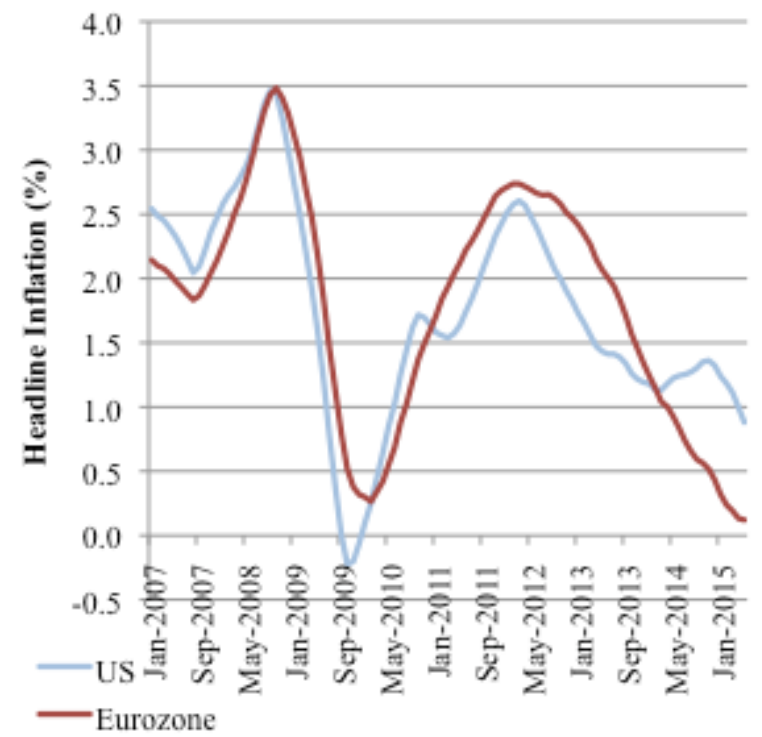

(b) Core inflation

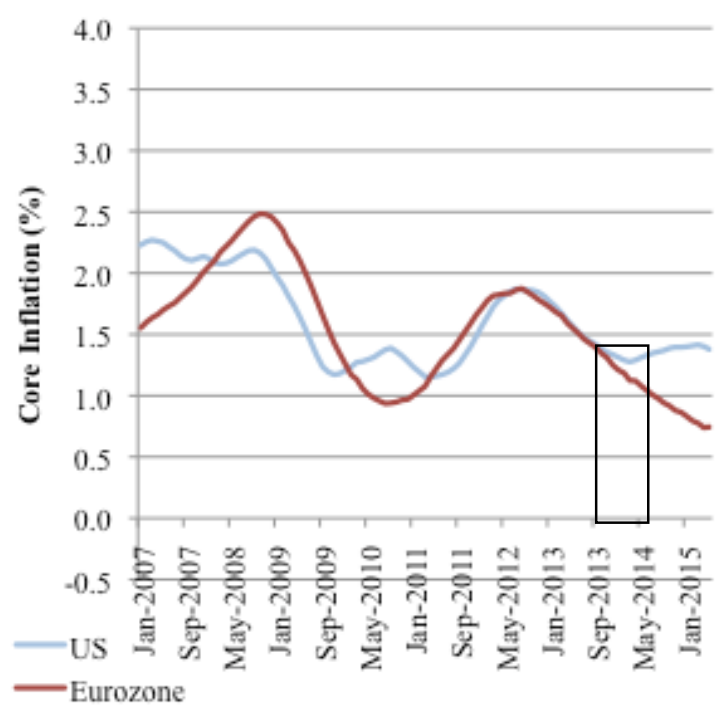

Sources: Federal Reserve Bank of St. Louis, for figure 8(a) "Personal Consumption Expenditures: Chaintype Price Index, Index 2009=100, Monthly, Seasonally Adjusted," and for figure 8(b) "Personal Consumption Expenditures Excluding Food and Energy (Chain-Type Price Index), Index 2009=100, Monthly, Seasonally Adjusted"; Eurostat, for figure 8(a) "All-items HICP," Index, 2005=100, monthly data, and for figure 8(b) HICP "Overall index excluding energy and unprocessed food," Index, 2005=100, monthly data.

Note: The inflation rate is calculated from the index as follows: $\ln (t)-\ln (t-12)$, where $t$ is the index for the current month. Subsequently, the rate is smoothed by taking the average rate over the past twelve months.

The Fed acknowledged the rise in inflation but even as early as their meeting on June 22-23, 2010, many FOMC members cited the risk of deflation. ${ }^{132}$ They noted that, "a continuation of lower-than-expected inflation and high unemployment could eventually lead to a downward movement in inflation expectations that would reinforce disinflationary pressures." ${ }^{\prime 33}$ Even though inflation was still on the rise at the November

\footnotetext{
132 Federal Reserve System (2010a).

${ }^{133}$ Federal Reserve System (2010a).
} 
2-3 meeting, FOMC members were still worried about deflation; they reassured themselves that "that the stimulus provided by additional securities purchases would help protect against further disinflation and the small probability that the U.S. economy could fall into persistent deflation." "134 And even inflation continued to rise, Bernanke said that the episode of inflation would be "transitory." 135

The second round of the Fed's quantitative easing program continued through to June 2011, after which it did pause. But on August 9, the FOMC strengthened its "forward guidance." The announcement said: "The Committee currently anticipates that economic conditions ... are likely to warrant exceptionally low levels for the federal funds rate at least through mid-2013." "136 The announcement was followed by a jump in the length of time over which market participants expected rates to remain unchanged, and the expected path of interest rates fell. ${ }^{137}$

QE and forward guidance had stemmed the rise in the value of the U.S. dollar, which had helped keep import prices up. The Fed was, therefore, supporting economic recovery through lower interest rates and a weaker dollar while also trying to raise price inflation. $^{138}$

Operating in parallel, the ECB's perspective could not have been more different: the ECB read the same data to raise interest rates twice in that same period. In June 2010, with some members of the FOMC already worried about deflation, a reporter said to Trichet, "many economists say that there is a clear risk of deflation." Trichet responded:

\footnotetext{
${ }^{134}$ Federal Reserve System (2010b). Once again, this view was challenged in the U.S. public debate. In an open letter to Ben Bernanke, many prominent economists warned that monetary stimulus would unleash uncontrolled inflation (Asness et al., 2010). But, as before, this view remained marginal.

135 De Leo and Derby (2011).

${ }^{136}$ Federal Reserve System (2011).

137 Woodford (2012, pp. 17-20).

${ }^{138}$ Mody (2014).
} 
"I don't think that such risks could materialise. On the contrary, inflation expectations are remarkably well anchored in line with our definition—less than $2 \%$, close to $2 \%$-and have remained so during the recent crisis. As regards the economy, the idea that austerity measures could trigger stagnation is incorrect." ${ }^{\prime 139}$

The ECB was unable to stop agonizing about inflation. In January 2011, the ECB's Governing Council kept the policy rate at 1 percent—where it had been since May 2009. But at his press conference, Trichet said that in view of the positive momentum in economic activity, the upward inflationary pressures needed monitoring. He, therefore, described the decision to keep the interest rate unchanged as "accommodative." ${ }^{140}$ His claim, in other words, was that the ECB was helping by not raising interest rates. When asked whether the attention to inflation was distracting the ECB from helping euro area countries in crisis, Trichet answered: "We do not see a dilemma in terms of hampering growth." ${ }^{" 141} \mathrm{He}$ referred to the July 2008 decision to raise the policy rate and maintained that it had appropriately provided price stability. The ECB, he said, was supporting financial stability through liquidity provision. At the February press conference, he used similar reasoning for maintaining rates.

By March, the ECB had concluded that the inflationary pressures required "strong vigilance." For this reason, Trichet repeated that the ECB remained "accommodative" and had held back from raising rates only because of the financial turbulence. ${ }^{142}$

\footnotetext{
${ }^{139}$ Polidori (2010).

${ }^{140}$ Trichet and Constâncio (2011a).

${ }^{141}$ Trichet and Constâncio (2011a).

142 Trichet and Constâncio (2011b).
} 
And then, as was widely expected, the policy rate was raised by 25 basis points on April 7. ${ }^{143}$ At the press conference, Trichet justified the hike as necessary to "firmly anchor" inflation. ${ }^{144}$ This was three days after Bernanke had commented that inflation was likely to be transitory. A reporter expressed concern that the rate was being raised prematurely; others worried about the effects on financially stressed peripheral economies. ${ }^{145}$ Some remarked that the ECB got it wrong in July 2008 and might be making the same mistake a second time. ${ }^{146}$ Trichet's hawkish comments at the press conference worried some market participants. One analyst said: "These remarks leave the door open for a follow-up rate hike from the ECB despite Trichet's insistence that the Governing Council had not decided to carry out a 'series' of hikes." ${ }^{147}$ Stock prices fell faster than implied by the trend of the past 20 days.

Although the policy rate was kept unchanged in May and June, the call for "strong vigilance" was repeated, indicating that another interest rate rise was likely soon. ${ }^{148}$ And, indeed, the rate was raised by 25 basis points on July 7 . Although Trichet acknowledged that economic growth had moderated, he emphasized there still was a "positive underlying momentum of economic activity in the euro area."149 As such, he said, it was of "paramount importance" to prevent the spread of inflationary pressures fueled by rising energy prices. He underlined that controlling inflation was essential to preserving the central bank's credibility. ${ }^{150}$ Although the decision was not a surprise,

\footnotetext{
${ }^{143}$ Carrel (2011) and Trichet and Constâncio (2011c).

${ }^{144}$ Censky (2011a) and Carrel (2011).

145 Trichet and Constâncio (2011c).

${ }^{146}$ Ignacio Crespo (2011), Kaiser and Felsenthal (2011).

${ }^{147}$ Carrel (2011).

148 Trichet and Constâncio (2011d).

149 Trichet and Constâncio (2011e).

${ }^{150}$ Censky (2011b).
} 
stock prices fell faster than the recent trend. Once again, observers noted that Trichet's statement "leaves the door open to more hikes," with one analyst predicting: "it is obvious that the ECB has further to go, there will be one more rate hike at least this year." ${ }^{151}$ This worried market analysts, who were increasingly concerned about slowing economic growth and the tensions in the debt markets. "We are not seeing the inflation risk that the ECB is seeing," said one such analyst. ${ }^{152}$ Trichet did, however, announce that the credit rating threshold would be lowered for Portuguese banks so that they would not denied the right to borrow from the ECB. ${ }^{153}$

The two rate hikes in April and July had raised the ECB's policy rate to 1.5 percent. Financial turbulence a few days before the August press conference prompted Trichet to recognize that "... downside risks may have intensified." ${ }^{154}$ But there was no change in the policy rate. By the September press conference, the ECB's assessment of growth prospects had become even more pessimistic. Trichet said: "Looking ahead, a number of developments seem to be dampening the underlying momentum in the euro area, including a moderation in the pace of global growth, related declines in equity prices and in business confidence, and unfavorable effects resulting from ongoing tensions in a number of euro area sovereign debt markets. As a consequence, real GDP growth is expected to increase very moderately in the second half of this year." ${ }^{\prime 55}$ But despite the tighter financial conditions, Trichet insisted that the ECB's stance was still

\footnotetext{
151 Thesing and Black (2011a).

${ }^{152}$ Ewing and Werdigier (2011).

${ }^{153}$ Reuters (2011).

154 Trichet and Constâncio (2011e).

155 Trichet and Constâncio (2011f).
} 
"accommodative." ${ }^{156} \mathrm{He}$ emphasized that the decision to maintain rates was unanimous and that no member of the Governing Council had argued for an interest rate cut. ${ }^{157}$

Trichet's actions had influential supporters. The BIS saw the fight against inflation in much the same way as Trichet did: as necessary to maintain price and financial stability. In implied criticism of the Fed and defense of the ECB, the BIS, in its June 2011 report, said: "[...] policy rates are too low. The current loose stance of monetary policy therefore reinforces concerns about risks to price stability. At the same time, it may foster a renewed buildup of risks to financial stability."158

The opposing view, bluntly expressed by Paul Krugman, was: "Adding to the [euro area's] problem is the E.C.B.'s obsession with maintaining its 'impeccable' record on price stability: at a time when Europe desperately needs a strong recovery, and modest inflation would actually be helpful, the bank has instead been tightening money, trying to head off inflation risks that exist only in its imagination." ${ }^{159}$ Hetzel, in his analysis of the rate hikes in 2011, favored the Krugman view, arguing that those hikes had come at a moment when the euro area economy was weak and commodity price inflation could have been reasonably expected to reverse.

It was time for Trichet to hand over the baton after 8 years as ECB President. The euro area was about to enter a particularly stressful period. The Fed had had its policy rate at $0-0.25$ percent since December 2008. The ECB's rate was 1.5 percent. It was only a matter of time; the rates cuts did come—-but soon the threat of deflation was growing.

\footnotetext{
156 Trichet and Constâncio (2011f).

157 Trichet and Constâncio (2011f).

158 BIS (2011, p. 61).

${ }^{159}$ Krugman (2011).
} 


\section{The Unwillingness to Preempt Deflation}

Mario Draghi succeeded Trichet as ECB President on November 1, 2011. Starting

November 3 2011, the ECB under Draghi tried to regain lost ground. But it was only two years later, on November 13,2013 , that the policy rate was finally brought down to 0.25

percent. The rate was further lowered to 0.05 percent by September 2014. In between, in June 2014, the ECB also announced that rather than paying interest to banks on funds that they deposited at the ECB, the banks would have to pay a fee to park money at the ECB - this was described as a "negative" interest rate. The intention, presumably, was that banks would seek income sources and thus lend more to households and businesses.

Our event study analysis suggests that markets reacted adversely to the postDraghi rate cuts. On average, following the rate cut, the abnormal difference was around negative 2 percent (Figure 9). Of the seven rate cuts, three came as a surprise to market participants, who seem to have lowered their expectations regarding the likely pace of monetary stimulus. Unexpected cuts, on average, showed an initial positive abnormal difference of 1 percent, but then fell steadily, reaching the same negative 2 percent as expected cuts. This loss in market momentum in the later days and the negative outcome for the unexpected cuts is statistically significant. 
Figure 9: Expected and Unexpected Rate Cuts, 2011-2014

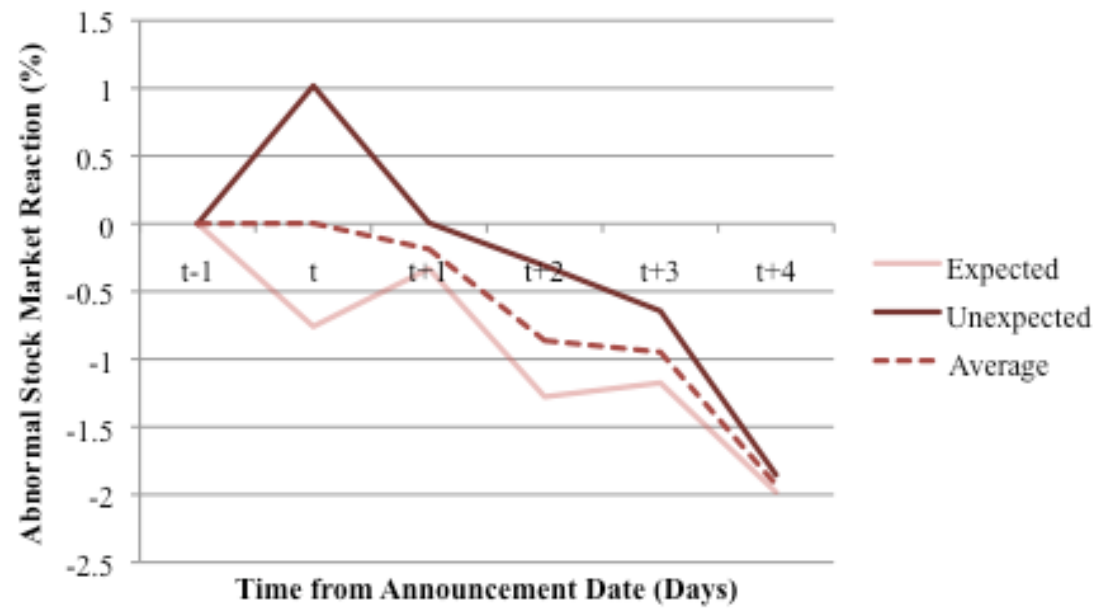

Note: There were 7 rate reductions by the ECB during this period. Of these, 3 were unexpected. Although, the average is clearly negative, 2 of the 7 announcements had a positive outcome, measured either on the $4^{\text {th }}$ day or as average of the $3^{\text {rd }}$ to the $5^{\text {th }}$ days. "t- 1 " refers to the market closing stock price on the day before the announcement. The market reaction is measured as the abnormal difference starting with the market closing price on the day of the announcement (" $t$ ") and on the following four days. The abnormal difference is measured as the cumulative change relative to the change based on a continuation of the past 20-day trend.

Although now in kinder words, the market commentary continued to tell a story of disappointment. The markets perceived Draghi as more proactive, but by this stage, rate cuts had lost their appeal. When the ECB announced a 25 basis points rate reduction after Draghi's first rate-setting meeting on November 3, the initial response was favorable. The Wall Street Journal reported: “[...] this is a sign that the ECB is finally waking up to the fact that financial conditions are too tight in Europe, and that's good news." ${ }^{160}$ But after the brief surge in the hours after the announcement, abnormal differences fell steadily into deeper negative territory. Draghi had hinted that the euro area may be falling back into recession but had rejected calls to scale up the bond-buying

${ }^{160}$ Gongloff (2011). 
program. ${ }^{161}$ A critical view gained ground: "[The latest] move, while welcome, was too modest, given the problems faced by the European economy."162

Interest rates were lowered by 25 basis points on December 8 , as widely expected. ${ }^{163}$ The ECB also announced a number of measures to ease credit flows. To encourage banks to lend, banks would have access to stable funding under the newlyconstituted longer-term refinancing operations (LTROs). The standards for collateral required to borrow from the ECB were lowered by, for example, bringing down the rating threshold for asset-backed securities that could be used as collateral. ${ }^{164}$ And the reserve ratio, which determines the minimum amount of reserves a bank must hold with the ECB, was lowered from 2 to 1 percent. None of this helped. Abnormal differences fell steadily, down by more than 6 percent on the $4^{\text {th }}$ day after the announcement. Draghi's words and actions were not well matched. A week earlier, Draghi had hinted that "other elements might follow," which was read as a signal that the ECB would step up bond purchases to lower longer-term interest rates, as the Fed had done under its quantitative easing programs. ${ }^{165}$ Instead, the continued absence of an "ECB bond buying bazooka," apparently, "roiled markets." "166 It did not help that on the same day, German Chancellor Angela Merkel said that no "big-bang" solution should be expected. ${ }^{167}$

${ }^{161}$ CNN Money (2011) and Kuehnen (2011).

162 CNN Money (2011).

163 Thesing and Black (2011b).

${ }^{164}$ European Central Bank (2011).

165 McHugh (2011).

166 Thesing and Meier (2011).

167 Thesing and Meier (2011) and BBC News (2011). Merkel was meeting with other European leaders at Marseille. The leaders had agreed to pursue a tax and budget pact outside the EU's legal framework, because the UK had blocked a change to the EU treaties. The European Stability Mechanism (ESM) - the euro area's "bailout fund" - was capped at $€ 500$ billion, and it was decided that the ESM and the European Financial Stability Facility would not run at the same time. 
The ECB waited half-a-year before lowering rates again. On July 5, 2012, accompanying a widely expected 25 basis points cut in the policy rate was a more surprising cut in the deposit rate (the rate at which banks place overnight deposits at the central bank) from 25 basis points to zero. Analysts were cautiously optimistic about reduction in the deposit rate. "It's not a silver bullet, but everything helps," said one observer. ${ }^{168}$ And, yet, markets responded adversely. The key question for some was "how far" the ECB would "go into unconventional measures to stabilize the economy and save the euro." 169 Other analysts were similarly concerned that the ECB was running out of conventional policy tools. ${ }^{170}$ These concerns were reinforced by Draghi, who was skeptical that more could be done in the financially "fragmented" European market.

Rate cuts went on pause for almost a year. On May 2, 2013, the policy rate was reduced by 25 basis points to 0.50 percent. In a Bloomberg news survey, 45 of 70 economists had anticipated the cut. ${ }^{171}$ The market response on this occasion was favorable. Market participants were not impressed by the cut, but the possibility that unconventional measures may be on the way was welcomed. ${ }^{172}$ At the press conference, Draghi said that the ECB was in the early stage of discussions on how to kick-start the market in asset-backed securities and hinted the ECB could cut the deposit rate into negative territory. ${ }^{173}$

Headline inflation in the euro zone fallen quickly from an annual rate of $2 \frac{1}{2}$ percent at the start of the year to just above 11/2 percent in October (Figure 8a). Much of

\footnotetext{
168 Black and Randow (2012).

${ }^{169}$ Lawton and Feher (2012).

${ }^{170}$ Birnbaum (2012) and Wilson (2012).

${ }^{171}$ Radow and Black (2013).

172 Radow and Black (2013), Draghi and Constâncio (2013).

${ }^{173}$ Draghi and Constâncio (2013).
} 
this fall was attributed to the decline in commodity prices, which ECB officials maintained would reverse. The ECB did not acknowledge — or missed — a more persistent deflationary force on account of weak consumption and investment demand in large parts of the eurozone. This deficiency became clear by October as the slippage in the eurozone's core inflation could no longer be ignored, especially because core inflation in the U.S. had stabilized (Figure 8b).

On November 7, the ECB surprised markets with a rate cut of 25 basis points. ${ }^{174}$ Draghi said that the prospect of prolonged low inflation had prompted the cut. ${ }^{175}$ Several market participants praised the move as a counter to deflationary risk and the Financial Times said that the ECB deserved "to emerge with enhanced credibility." 176 But the abnormal stock prices differences quickly turned negative despite favorable review of the action taken. The concern was that the ECB was backing itself into an "uncomfortable position." 177 Since even the rate cut appeared to have been controversial in the ECB's Governing Council, observers worried if the ECB had the ability to do the "big stuff."178 The dissonance with the market arose, once again, because of differences in the sense of urgency. Draghi insisted that the ECB had "a whole range of instruments that we can activate." ${ }^{179}$ But he was equally firm that the ECB would deploy additional measures only "if needed." Among others, Guntram Wolff of Bruegel called for more aggressive

\footnotetext{
${ }^{174}$ Irwin (2013).

175 BBC News (2013).

176 Barber (2013).

${ }^{177}$ BBC News (2013) and Black and Randow (2013).

178 Kennedy and Riecher (2013).

${ }^{179}$ Draghi (2013b).
} 
monetary policy. ${ }^{180}$ For some market observers, however, the ECB was already too late. ${ }^{181}$

Draghi repeatedly insisted during this phase that while inflation was low, the medium term outlook for inflation expectations remained "anchored." Thus, in April 2014, Draghi stated that the ECB would act only if inflation remained low for "too prolonged a period." 182 Draghi was asked what he meant by "too prolonged a period," but he had no clear answer. Despite a sharper slowdown in core inflation than in the United States since October 2013 (Figure 8), the message still was that euro area inflation had fallen mainly because of weakness in commodity prices, and so would reverse. Notice the asymmetry. When commodity prices were pushing inflation up, the ECB sought to nip it in the bud; but when commodity prices pushed inflation down, the ECB preferred to wait in anticipation of a return to more normal inflation rates.

On June 5, the ECB cut the policy rate by 10 basis points to 0.15 percent, while also lowering the deposit rate into negative territory. Both these moves were expected. ${ }^{183}$ The ECB also delivered on other promises, announcing a new liquidity program to encourage lending. ${ }^{184}$ Draghi signaled that he was willing to go further, leaving the door open to a bond-buying program. ${ }^{185}$ Analysts were pleased that the ECB was doing “everything short of full QE." 186 The announcements that day were read as a strong

\footnotetext{
${ }^{180}$ Wolff (2014).

${ }^{181}$ Black and Randow (2013).

${ }^{182}$ Draghi (2014a).

${ }^{183}$ BBC News (2014a).

${ }^{184}$ Black and Riecher (2014).

${ }^{185}$ Ewing and Irwin (2014a).

186 Thompson (2014).
} 
message that the ECB "is determined to put Europe on a path to stronger growth." 187 Markets were pleased, with abnormal differences ending positively by the fourth day.

Finally, on September 4, 2014 the ECB surprised markets with a 10 basis point reduction of the policy rate down to 0.05 percent. ${ }^{188}$ The ECB also announced it would embark upon an asset purchase program. Observers were initially pleased. ${ }^{189}$ Abnormal differences rose on the day after the announcement. The commentary was cautiously complimentary. "For years the ECB has been very slow to react and often frustrated markets," said one asset manager. "[Today], in the face of dire and clearly worsening economic indicators Draghi has actually gone beyond markets' expectations. [...] it is certainly progress. ${ }^{190}$ Despite such favorable reviews, the mood changed quickly and the abnormal differences fell into negative territory. The concern was that deflationary tendencies would prove hard to reverse. Headline inflation had fallen to 0.3 percent by August 2014. As Andrew Balls, a senior executive at the bond investor PIMCO, said some weeks later, "The eurozone is one shock away from sinking into deflation. There are real costs of acting too late." ${ }^{191}$

The QE did come. On January 22, 2015, the ECB announced it would "add the purchase of sovereign bonds to its existing private sector asset purchase programmes," with combined monthly purchases amounting to $€ 60$ billion. ${ }^{192}$ Purchases started on March 9 and are expected to continue until at least September 2016.

\footnotetext{
${ }^{187}$ Ewing and Irwin (2014a).

${ }^{188}$ Horta e Costa (2014). Not surprisingly, Jurgen Stark, who was now no longer at the ECB, described the move as sign of "desperation," arising from "feverish" preoccupation with deflation (Stark, 2014).

${ }^{189}$ Ewing and Irwin (2014b).

190 BBC News (2014b).

191 Balls (2014).

192 European Central Bank (2015a).
} 
Once again, we must ask why the ECB continued to act slowly, this time allowing deflationary tendencies to set in. Unlike between 2007 and 2009, the Fed could not be easily accused of reckless behavior and the eurozone was more clearly in the doldrums; hence, there was little rhetorical leverage in criticizing the U.S. Instead, to differentiate the ECB's sedate actions from the Fed's forceful measures, Draghi used a more structural argument. He noted that 80 percent of financial intermediation in the euro area was done by banks, whereas financial markets played a much bigger role in the United States. ${ }^{193}$ The implication, he argued, was that quantitative easing would have a smaller impact in the euro area and, thus, its introduction was not urgent.

Optimistic rhetoric again played an important role. In March 2012, as it was becoming clear that the euro area economy was contracting, Draghi said that he expected the economy to "stabilize," with gradual recovery later in 2012 . He noted that interest rates were "very" low and, importantly, he claimed that the sense of risk and uncertainty in the global economy had declined. ${ }^{194}$ Draghi reiterated the ECB's time-honored advice for national governments to boost growth through structural reforms. Although he recognized that such reforms generally help lift growth only with a lag, Draghi said they would deliver immediate dividends by increasing confidence in the future. A few months later, at the June 6 press conference, an incredulous reporter asked Draghi if he was aware of how bad things were and of the extent of panic in the markets. ${ }^{195}$ Draghi acknowledged that "downside risks" were high. But he restated that there also were positive signals: interest rates were low and buoyant foreign demand would help. Thus,

\footnotetext{
${ }^{193}$ Draghi (2013a).

${ }^{194}$ Draghi (2012a).

${ }^{195}$ Draghi (2012b).
} 
"modest improvement" could be expected. In other words, Draghi's message was that things could go badly wrong but the ECB was counting on that not happening. That optimism — more appropriately, wishful thinking — did not quite pan out. Starting the first quarter of 2012, the euro area contracted for seven straight quarters.

The reluctance to deal with deflation has been recounted in detail above, but one encounter with a journalist is revealing. At the press conference on November 7, 2013, the journalist described the ECB as a "pea-shooter dealing with an approaching deflationary tank," and asserted that financial markets had given up on the possibility of decisive action. ${ }^{196}$ Once again, Draghi acknowledged that things had, indeed, become worse: the slowdown in inflation had spread across more goods and services and across more countries. But, he said, that the ECB was waiting for more data. He insisted that the ECB was taking action and would do more, "if needed." In effect, Draghi was saying: we will not jump ahead—we will respond.

As between 2007 and 2009, the Europe-is-different theme and optimistic interpretation of the economic data were, in part, needed as covers for the hold-up due to the disagreements in the ECB's Governing Council. Draghi reported on the disagreements and, on one occasion, even identified the dissenter: the new Bundesbank President, Jens Weidmann. For months, Weidmann insisted on moving ahead slowly and cautiously. These Governing Council differences were mirrored in the political debate. The Germans and their "Northern" allies pushed back French Presidents Sarkozy and Hollande who kept pressing the ECB to do more for growth. ${ }^{197}$ Thus, once again,

\footnotetext{
${ }^{196}$ Draghi (2013b).

${ }^{197}$ Blackstone and Karnitschnig (2012); Barre (2011) for a French and Costas (2013) for a similar Spanish view.
} 
heterogeneity of national interests slowed down the decision-making. But the asymmetry in dealing with inflation and deflation also suggests that the ECB has internalized an ideological bias against inflation, a bias that runs so deep that the deflationary tendencies are — possibly, subconsciously_-welcomed as a safeguard against inflation.

\section{Central Bank Credibility}

As of this writing (in December 2015), the euro area economic recovery has been decidedly weaker (GDP is just about at the pre-crisis level) and core inflation rate remains stuck below a 1 percent annual rate. Core inflation is particularly low in important member states, including Italy and Spain. Thus, despite the decline in nominal interest rates, they face high real interest rates (Figure 10). These countries will continue to struggle to lower their public and private debt burdens and hence risk remaining trapped in a low-growth, high-debt environment in the near future. In contrast, Germany, with a negative real interest rate is benefiting from monetary stimulus. 


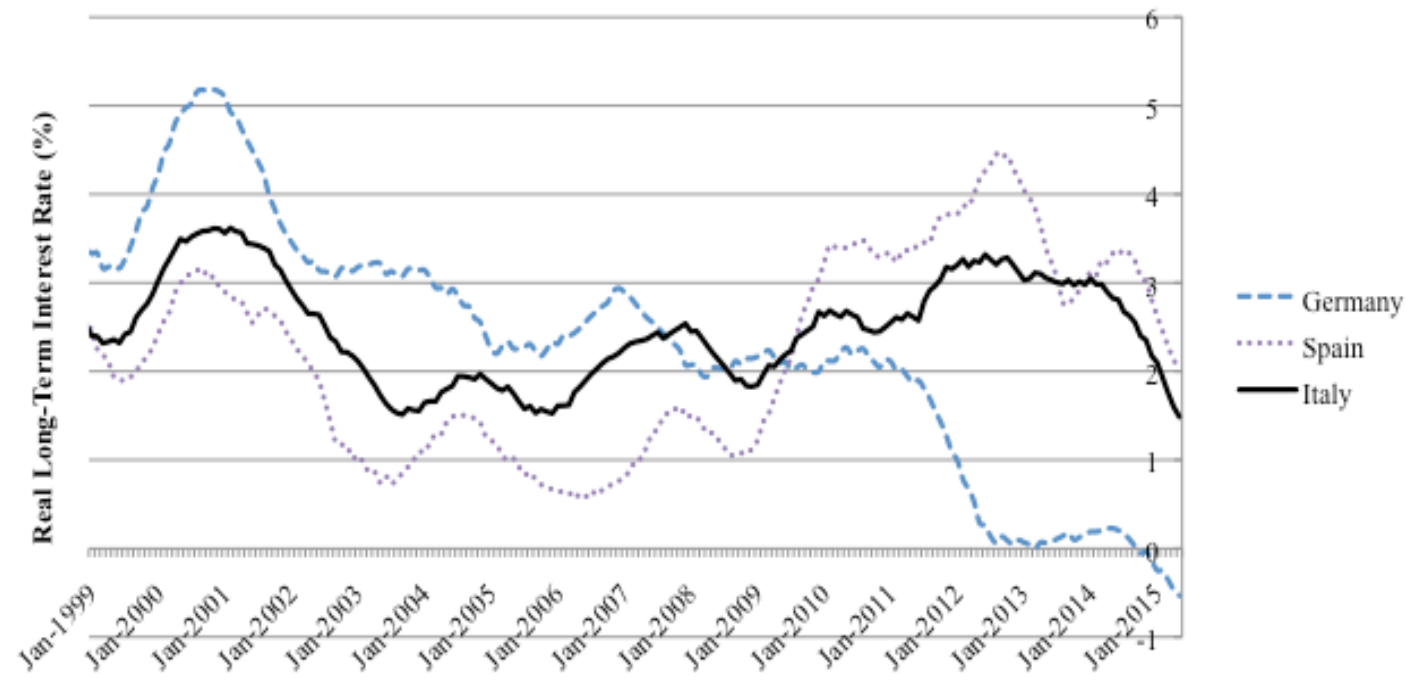

Sources: "Long-term interest rate" available from stats.oecd.org. Core inflation: HICP "Overall index excluding energy and unprocessed food." Available from ec.europa.eu/eurostat/web/hicp/data/database; Note: The nominal interest rate is smoothed by taking the average rate over the past twelve months. Annual inflation is computed as the moving 12-month average of monthly year-on-year change. The real interest rate is calculated as $r=(1+i) /(1+\pi)-1$. Where $i$ is the nominal interest rate, and $\pi$ is the inflation rate.

On December 3, the ECB announced several new measures in the hope of stimulating economic activity and inflation. Stock markets "tumbled because, said the Wall Street Journal, "the European Central Bank served up a package of stimulus measures that fell well short of many investors' expectations." 198 This paper tells the story of how we reached this point. The Fed acted early and, despite lapses, conveyed a consistent message that it would use monetary policy to create an economic and financial shelter from the gathering storm. By thus establishing the premise that it was prepared, the Fed was able to establish the benchmarks by which its seriousness of purpose would be judged. Indeed, when the Fed hesitated or strayed from the clarity of its message by 
referring to worries about inflation, the adverse market feedback came quickly. To the Fed's credit, it typically read the market's message quickly and correctly.

The ECB was always ready to provide liquidity to banks, and, indeed, was briefly one step ahead of the Fed in this regard on August 9, 2007. But the ECB also made it clear that its macroeconomic priority was to fight inflation. The policy interest rate was, therefore, increased in July 2008, and was reduced only under the threat of global financial meltdown in October 2008. Markets, therefore, gave the ECB little credit for the rate cuts from October 8 to May 2009.

After the brief global economic recovery in 2010, the ECB responded to renewed commodity price inflation by hiking interest rates twice in 2011 . These hikes, Trichet said, were justified because subduing inflation also enhanced financial stability. ${ }^{199}$ As in July 2008, the ECB was fighting an enemy that, though fearsome at time, was in retreat.

When the inevitable interest rates cut did come, starting in November 2011, observers were kind but markets were not. More clearly than in the 2008-9 period, the market reaction was adverse. The ECB had been forced to reverse its rate increases under the pressure of worsening economic and financial conditions. Moreover, it was soon clear the euro area was slipping into a phase of persistent low inflation, with outright deflation in some member states. Markets called for ever more forceful action, but the ECB delivered in half measures.

ECB officials have often justified their decisions on the basis that price stability is its primary mandate. Bini Smaghi, in a June 2009 speech, emphasized that the ECB was guided by the goal of maintaining inflation at less than but close to 2 percent over the

${ }^{199}$ Trichet and Papademos (2007b). 
medium term. Short-term initiatives to pump up growth through easier monetary policy, he said, risked sparking inflation in the medium-term. ${ }^{200}$ With a not-so-veiled reference to the U.S. Federal Reserve, he said, "if a central bank is concentrated on near-term results, on the pursuit of growth at all costs, this leads it to conduct policies that increase instability." ${ }^{201}$ Similarly, in September 2011, Trichet highlighted the price stability mandate, which he said had delivered an average inflation rate of 1.55 percent since the introduction of the euro. ${ }^{202}$

While the ECB had a mandate to maintain price stability, in the years before the crisis, it had paid attention to economic activity, as Taylor and Nechio had independently shown. ${ }^{203}$ Indeed, Taylor found that between 2000 and 2006, when the Fed's rate fell below that implied by the Taylor's rule, so eventually did the ECB's, as if the ECB was following the Fed's lead. Once the crisis started, the Fed placed its focus on the risk of prolonged recessionary conditions. The ECB firmly diverged from the Fed's stance. Trichet emphasized in his press conferences that since the two central banks were equally committed to maintaining price stability, the Fed's difference in approach likely reflected imbalances that were specific to the U.S. economy. ${ }^{204}$ Whatever the specific U.S. imbalances, the Fed saw more clearly that inflation was not a threat. As Mishkin, a former Governor of the Federal Reserve System, later remarked, low interest rates did not create the risk of a credit-fueled uncontrollable inflation when financial institutions were deleveraging. ${ }^{205}$

\footnotetext{
${ }^{200}$ Bini Smaghi (2009).

${ }^{201}$ Atkins (2009c).

202 Trichet and Constâcio (2011f).

${ }^{203}$ Taylor (2010) Nechio (2011).

${ }^{204}$ Trichet and Papademos (2008b).

${ }^{205}$ In the general discussion following Svensson (2011), p. 346.
} 
What does the Fed's success tell us about central bank credibility? After all, the commonly held view emphasizes that a steadfast commitment to containing inflation is the touchstone of central bank credibility. ${ }^{206}$ Taken literally, the ECB acted properly and the Fed did not.

The Fed, however, operated on a broader view of central bank credibility, one which incorporates the need and ability to deal with contingencies. Under the gold standard, for example, the monetary policy objective was to maintain the value of the currency relative to gold. But it was also considered reasonable to depart from that commitment in extraordinary circumstances, as Bordo and Kydland have explained. ${ }^{207}$ Despite the departure from the rule, credibility is maintained when the central bank's return to its original commitment can be presumed once circumstances normalize.

The markets accepted — indeed, welcomed — the premise that countering the Great Recession merited unusual action. The Fed gained credibility by departing from the single-minded pursuit of containing inflation. As Blinder emphasizes, more so than managing inflation, credibility is achieved by matching deeds to words. ${ }^{208}$ The Fed learned towards the end of 2007 that attempting to juggle two balls - controlling inflation and achieving financial stability to revive confidence and growth — would send mixed messages and dilute the pursuit of both objectives. The focus on a clear goal helped match deeds to words, and to thereby retain credibility.

If, as is entirely possible, the euro area's core inflation rate remains below 1 percent a year - and even if the eurozone does not fall into outright deflation - the ECB's

\footnotetext{
206 Blinder (2000).

${ }^{207}$ Bordo and Kydland (1995).

${ }^{208}$ Blinder (2000, p. 1422) and Blinder (2012) for a similar analysis of the Fed's credibility during the Great Recession.
} 
credibility will be twice hurt. Not only would it have failed to provide stimulus when needed, but by allowing the euro area to slip into a low inflation trap, it would have failed also in maintaining the inflation rate close to 2 percent a year. With a eurozone-wide inflation rate of less than 1 percent, some countries will experience close to zero or even negative inflation rates. They will face high real interest rates, stymying their ability to recover. The loss of monetary traction will hurt all the more so because large segments of euro area small- and medium-banks remain under stress and the fiscal stance, though no longer contractionary, is not stimulative either. ${ }^{209}$

\section{References}

Aït-Sahalia, Yacine, Jochen Andritzky, Andreas Jobst, Sylwia Nowak, and Natalia Tamirisa, 2012, "Market Response to Policy Initiatives during the Global Financial Crisis," Journal of International Economics 87(1): 162-177.

Akerlof, George and Robert Shiller, 2009, "Animal Spirits: How Human Psychology Drives the Economy, and Why It Matters for Global Capitalism," Princeton: Princeton University Press.

Andrews, Edmund and Jeremy Peters, 2007, "Markets Soar after Fed Cuts Key Rate by a Half Point," The New York Times, September 18.

Andrews, Edmund, 2007, “A Rate Cut by the Fed, but a Sense It Stops Here," The New York Times, November 1.

Andrews, Edmund, 2008, "Fed Cuts Key Interest Rate by $3 / 4$ of a Point," The New York Times, March 18.

Andrews, Edmund and Jacky Calmes, 2008, "Fed Cuts Key Rate to a Record Low," The New York Times, December 16.

Appelbaum, Binyamin, Peter Eavis, Annie Lowrey, Nathaniel Popper and Nelson Schwartz, 2014, “The Fed's Actions in 2008: What the Transcripts Reveal," February 21.

Asness, Cliff, 2010, “Open Letter to Ben Bernanke," Wall Street Journal Real Time Economics, November 15, http://blogs.wsj.com/economics/2010/11/15/open-letter-toben-bernanke/.

${ }^{209}$ Mody and Wolff (2015) and Mody (2015). 
Atkins, Ralph, 2008a, "ECB raises interest rates to 4.25\%," The Financial Times, July 3.

Atkins, Ralph, 2008b, "ECB set to cut rate by at least half a point," The Financial Times, November 28.

Atkins, Ralph, 2008c, "Eurozone inflation surges to 16-year high," The Financial Times, March 31.

Atkins, Ralph, 2008d, "European growth rates pull in different directions," The Financial Times, April 9.

Atkins, Ralph, 2008e, "Schadenfreude stirs in resilient Germany," The Financial Times, April 10.

Atkins, Ralph, 2008f, "Eurozone warned on impact of credit crisis," The Financial Times, April 10.

Atkins, Ralph, 2009a, "ECB cuts rates to lowest in three years," The Financial Times, January 15.

Atkins, Ralph, 2009b, “ECB's cautious cut strengthens euro," The Financial Times, April 2.

Atkins, Ralph, 2009c, "ECB official criticizes failure to focus on inflation," The Financial Times, June 26.

Atkins, Ralph, 2011, "ECB raises interest rates to 1.5\%," The Financial Times, July 7.

Balls, Andrew, 2014, "ECB inflation target fails credibility test," The Financial Times, November 19.

Bank of International Settlements, 2008, “78 ${ }^{\text {th }}$ Annual Report,” June 30.

Bank of International Settlements, 2011, “81 ${ }^{\text {st }}$ Annual Report,” June 26.

Barr, Colin, 2008, "Why the Fed's not done cutting rates," Fortune, April 30.

Barber, Tony, 2008, "Europe blames market turmoil on US fiscal policy," The Financial Times, January 22.

Barber, Tony, 2013, "ECB rate cut shows economic recovery anything but secure," The Financial Times, November 7.

Barre, Nicolas, 2011, “Le message de la BCE,” Les Echos, December 9.

Bernanke, Ben, 2011, "Press Conference with the Chairman of the FOMC," April 27. 
BBC News, 2008a, "Fed slashes rates in shock move," January 22.

BBC News, 2008b, “Central banks cut interest rates,” October 8.

BBC News, 2009a, "Euro rates and growth outlook cut," March 5.

BBC News, 2009b, "ECB reduces rates to record low," April 2.

BBC News, 2011, "Euro crisis: UK alone as Europe agrees fiscal compact," December 9.

BBC News, 2013, “ECB cuts interest rates to record low,” November 7.

BBC News, 2014a, “ECB imposes negative interest rate,” June 5.

BBC News, 2014b, “ECB cuts rates and launches stimulus programme,” September 4.

Bernanke, Ben, 2007, "The Subprime Mortgage Market," at the Federal Reserve Bank of Chicago's 43rd Annual Conference on Bank Structure and Competition, Chicago, Illinois, May 17, http://www.federalreserve.gov/newsevents/speech/bernanke20070517a.htm.

Bernanke, Ben, 2010, "The Economic Outlook and Monetary Policy," Federal Reserve Bank of Kansas City Economic Symposium, August 27.

Bini Smaghi, Lorenzo, 2009, "Inflation and deflation risks: How to recognise them? How to avoid them?” XXI Villa Mondragone International Economic Seminar, June 24.

Birnbaum, Michael, 2012, "Europe, China lower rates in urgent effort to spur recovery," The Washington Post, July 5.

Black, Jeff and Gabi Thesing, 2011, "ECB Unexpectedly Lowers Rate to $1.25 \%$ as

Draghi Signals No Debt Backstops," Bloomberg, November 3.

Black, Jeff and Jana Randow, 2012, "ECB Cuts Main Rate to Record Low, Deposit Rate to Zero," Bloomberg, July 5.

Black, Jeff and Jana Randow, 2013, "ECB Cuts Key Rate to Record Low to Fight Deflation Threat," Bloomberg, November 7.

Black, Jeff and Stefan Riecher, 2014, "Draghi Unveils Historic Measures Against Deflation Threat," Bloomberg, June 5.

Blackstone, Brian and Matthew Karnitschnig, 2012, "Head of Bundesbank: No Apologies," Wall Street Journal Online, April 24. 
Blanchard, Olivier, Eugenio Cerutti, and Lawrence Summers, 2015, "Inflation and Activity: Two Explorations and Their Monetary Policy Implications," Peterson Institute Working Paper Series WP 15-19, November, http://www.piie.com/publications/wp/wp15-19.pdf.

Blinder, Alan, 2010, “Central-Bank Credibility: Why Do We Care? How Do We Build It?” American Economic Review 90(5): 1421-1431.

Blinder, Alan, 2012, "Central Bank Independence and Credibility During and After a Crisis," Griswold Center for Economic Policy Studies Working Paper No. 229, September, Paper presented at the 2012 Federal Reserve Bank of Kansas City Economic Policy Symposium, The Changing Policy Landscape, in Jackson Hole, Wyoming, on September 1, 2012. http://www.princeton.edu/ceps/workingpapers/229blinder.pdf.

Blinder, Alan, 2013, “After the Music Stopped: the Financial Crisis, the Response, and the Work Ahead," New York: Penguin Press.

Bloomberg Businessweek, 2008, “The ECB Pulls the Rate-Hike Trigger,” July 3.

Bohl, Martin, Pierre Siklos and David Sondermann, European Stock Markets and the ECB's Monetary Policy Surprises," International Finance 11 (2): 117-130.

Bordo, Michael and Finn Kydland, 1995, "The Gold Standard as a Rule: an Essay in Exploration," 32: 423-64.

Brockett, Matthew, 2007, "ECB Raises Interest Rate to 3.75\% to Stem Inflation (Update2)," Bloomberg, March 8.

Buiter, Willem, 2007, "Should the Fed raise interest rates?" Willem Buiter's Mavercon Blog, November 30, 2007, http://blogs.ft.com/maverecon/2007/11/should-the-fedhtml/\#axzz3kCcMg3th.

Buiter, Willem, 2008, “The Bernanke put: buttock-clenching monetary policymaking at the Fed," Willem Buiter's Mavercon Blog, January 22, http://blogs.ft.com/maverecon/2008/01/the-bernanke-puhtml/\#axzz3kysaxFzY.

Carrel, Paul, 2011, "ECB hikes rates, ready to move again if necessary," Reuters, April 7. CBS News, 2008, “Big Rate Cuts as Stock Markets Sink,” November 6. CBS News, 2009, “European Interest Rate Drops To 1.25\%,” April 2.

Cecchetti, Stephen, 2008, “The Fed's emergency interest cut: There's a new sheriff in town," VOX, January 22.

Censky, Annalyn, 2011a, "ECB raises rates to combat inflation," CNN Money, April 7. 
Censky, Annalyn, 2011b, “ECB hikes interest rates,” CNN Money, July 7.

CNBC, 2008, “Fed's Surprise Rate Cut Draws Mixed Response,” January 22.

CNN Money, 2009, “ECB: Slashes rate to record 1\%," May 7.

CNN Money, 2011, “European Central Bank cuts rates,” November 3.

Costas, Antón, 2013, “Alemania es parte del problema, no la solución,” El País, May 5.

Cotis, Jean Philippe, 2007, "Achieving Further Rebalancing," OECD Economic Outlook 81, June, http://www.oecd-ilibrary.org/docserver/download/eco_outlook-v2007-1-sumen.pdf? expires $=1441541294 \& \mathrm{id}=\mathrm{id} \&$ accname $=$ guest $\&$ checksum $=579 \mathrm{A0C} 8617 \mathrm{~F} 3907 \mathrm{~F} 0$ BD5EFAA9C2F6E23.

Coy, Peter, 2008, "Bernanke Attacks the Recession with Force," Bloomberg Businessweek, December 16.

D’Amico, Stefania and Thomas King, 2015, "What Does Anticipated Monetary Policy Do?” Federal Reserve Bank of Chicago, Working Paper 2015-10, November.

Di Leo, Luca and Sofia Celeste, 2008, "Berlusconi, Echoing Sarkozy, Faults ECB for Its Limited Role," Wall Street Journal, April 17.

Di Leo, Luca and Michael S. Derby, 2011, "Bernanke Plays Down Threats of Inflation," Wall Street Journal Online, April 5.

Dougherty, Carter, 2007, "ECB raises interest rates and signals that increases may continue," The New York Times, June 6.

Dougherty, Carter and Edmund Andrews, 2008, "Central Banks Coordinate Global Cut in Interest Rates," The New York Times, October 9.

Dougherty, Carter, 2008, "ECB cuts rate three-quarters of a point; Bank of England also lowers," The New York Times. December 4.

Dougherty, Carter, 2009, "Two Central Banks in Europe Cut Key Rates,” The New York Times, March 6.

Dougherty, Carter and Julia Werdigier, 2009, "Central Banks Act to Shore Up British and European Economies," The New York Times, May 7.

Draghi, Mario, 2012a, "Introductory statement with Q\&A," European Central Bank, March 8. 
Draghi, Mario, 2012b, “Introductory statement with Q\&A," European Central Bank, June 6.

Draghi, Mario, 2013a, "Introductory statement with Q\&A," European Central Bank, April 4.

Draghi, Mario, 2013b, “Introductory statement with Q\&A,” European Central Bank, November 7.

Draghi, Mario and Vítor Constâncio, 2013, "Introductory statement to the press conference (with Q\&A)," European Central Bank, May 2.

Draghi, Mario, 2014a, "Introductory statement with Q\&A," European Central Bank, April 3.

Draghi, Mario, 2014b, "Monetary policy in the euro area," the Frankfurt Banking Congress, November 21.

Eichengreen, Barry, Ashoka Mody, Milan Nedeljkovic, and Lucio Sarno, 2012, "How the Subprime Crisis went Global: Evidence from Bank Credit Default Swap Spreads," Journal of International Money and Finance 31(5): 1299-1318.

Elliott, Larry and Ashley Seager, 2008, "Federal Reserve slashes interest rates to nearly zero," The Guardian, December 17.

El País, 2008, “Rigor monetario,” July 4.

European Central Bank, 2007, “Box 3: The ECB's Additional Open Market Operations in the Period from 8 August to 5 September 2007," Monthly Bulletin, September.

European Central Bank, 2010, “The ECB's Monetary Policy Stance during the Crisis," Monthly Bulletin, January.

European Central Bank, 2011, “ECB Announces Measures to Support Bank Lending and Money Market Activity," December 8.

European Central Bank, 2015a, "ECB Announces Expanded Asset Purchase Programme," January 22.

European Central Bank, 2015b, "Euro Money Market Study 2014,” April, https://www.ecb.europa.eu/pub/pdf/other/euromoneymarketstudy2014.en.pdf?fe $5 \mathrm{~d} 27 \mathrm{f} 30$ $1323 \mathrm{e} 458 \mathrm{~d} 221 \mathrm{e} 1 \mathrm{f} 63642759$.

Ewing, Jack, 2011, “European Bank Raises Rate for $1^{\text {st }}$ Time Since 2008," The New York Times, April 7. 
Ewing, Jack and Julia Werdigier, 2011, "European Central Bank Raises Rates as Expected," The New York Times, July 7.

Ewing, Jack and Neil Irwin, 2014a, "European Central Bank Breaks New Ground to Press Growth," The New York Times, June 5.

Ewing, Jack and Neil Irwin, 2014b, “Europe's Bank Takes Aggressive Steps," The New York Times, September 4.

Fatas, Antonio and Lawrence Summers, 2015, "The Permanent Effects of Fiscal Consolidations," Centre for Economic Policy Research Discussion Paper No. 10902, October 2015.

The Federal Reserve System, 2007a, "Press Release,” August 10.

The Federal Reserve System, 2007b, "Press Release," September 18.

The Federal Reserve System, 2007c, "Press Release,” December 11.

The Federal Reserve System, 2008a, "Meeting of the Federal Open Market Committee on January 29-30, 2008,” January 29-30.

The Federal Reserve System, 2008b, "Meeting of the Federal Open Market Committee on March 18, 2008," March 18.

The Federal Reserve System, 2008c, "Meeting of the Federal Open Market Committee on April 29-30, 2008," April 29-30.

The Federal Reserve System, 2008d, "Minutes of the Federal Open Market Committee," April 29-30.

The Federal Reserve System, 2008e, "Press Release," January 22.

The Federal Reserve System, 2008f, “Press Release,” January 30.

The Federal Reserve System, 2008g, "Press Release," October 29-30.

The Federal Reserve System, 2008h, "Press Release,” December 16.

The Federal Reserve System, 2010a, "Minutes of the Federal Open Market Committee," June 22-23.

The Federal Reserve System, 2010b, "Minutes of the Federal Open Market Committee," November 2-3.

The Federal Reserve System, 2011, "Press Release,” August 9. 
Felsenthal, Mark, 2007, "Fed slashes interest rates to buffer economy," Reuters, September 18.

Fraher, John, 2009, “ECB Faces Day of Reckoning on New Policy Measures,” Bloomberg, April 3.

Gongloff, Mark, 2011, “ECB Cuts Rates, In Surprise Move,” The Wall Street Journal, November 3.

Goria, Fabrizio, 2011, "Draghi e la spending review non convincono i mercati," Linkiesta, July 5.

Gow, David, 2008, "ECB raises interest rates to 4.25\%," The Guardian, July 3.

Gow, David, 2009, "ECB cuts eurozone interest rate to 2\%," The Guardian, January 15.

Guerrera, Francesco and Ben White, 2008, "Sigh of relief at Goldman and Lehman results," The Financial Times, March 18.

Guha, Krishna 2008a, "How events persuaded the Fed chief to reveal his decisive side," The Financial Times, January 23.

Guha, Krishna, 2008b, "US stocks rally after Fed interest rate cut," The Financial Times, March 18.

Hanke, Steve, 2008, "Panic Time at the Fed," Forbes, April 18.

Hetzel, Robert, 2009, "Monetary Policy in the 2008-9 Recession," Economic Quarterly 95 (2): 201-233, https://www.richmondfed.org/ /media/richmondfedorg/publications/research/economic quarterly/2009/spring/pdf/hetzel2.pdf.

Hetzel, Robert, 2012, "The Great Recession: Market Failure or Policy Failure," Cambridge: Cambridge University Press.

Hetzel, Robert, 2014, "Contractionary Monetary Policy Caused the Great Recession in the Eurozone: A New Keynesian Perspective" The Federal Reserve Bank of Richmond Working Paper Series, August 22.

Hilsenrath, Jon and Kristina Peterson, 2013, “Fed 'Doves' Beat 'Hawks' In Economic Prognosticating: Officials' Predictions From 2009-2012 Scored for Accuracy on GDP Growth, Jobs and Inflation,” Wall Street Journal Europe, July 30.

Homburger, Antje, 2007, “ECB lifts key interest rate to 4 percent," USA Today, June 6. 
Hopkins, Kathryn, 2009, "Eurozone economy: European Central Bank cuts rates to historic low of 1\%," The Guardian, May 7.

Horta e Costa, Sofia, 2014, "European Stocks Rally to Two-Month High on ECB Boost," Bloomberg Businessweek, September 4.

Hughes, Krista and Marc Jones, 2009, "ECB signals March rate cut, markets bet on 50 bps," Reuters, February 5.

Ignacio Crespo, Juan, 2011, “La inflación engaña dos veces,” El País, April 8.

Inman, Phillip, 2011, "ECB cuts interest rates to 1.25\%," The Guardian, November 3.

Ip, Greg, 2007, "Bernanke, in his first major test, changes U.S. Fed's plan of attack: Chief solicits help, eases credit woes," Wall Street Journal Europe, November 1.

Irwin, Neil, 2007a, "Fed Cuts Key Rate More Than Expected," The Washington Post, September 19.

Irwin, Neil, 2007b, "Fed Cuts Key Interest Rate By Quarter Point; Stocks Fall," The Washington Post, December 12.

Irwin, Neil, 2013, "Super Mario to the rescue: The ECB cuts interest rates," The Washington Post, November 7.

Isidore, Chris, 2008a, “Fed delivers another rate cut,” CNN Money, January 30.

Isidore, Chris, 2008b, "Fed cuts rates by 3/4 of a point," CNN Money, March 18.

Isidore, Chris, 2008c, “Fed: Emergency cut,” CNNMoney, October 8.

Isidore, Chris, 2008d, "Fed cuts rates and gives grim view," CNN Money, October 29.

Izraelewicz, Erik, 2007, “Bravo la Fed” Les Echos blog, November 1.

Kaiser, Emily and Mark Felsenthal, 2011, "Seven reasons why the Fed won't follow the ECB," Reuters, April 7.

Kennedy, Simon, 2009, “ECB Interest-Rate Cuts May Fail to Rescue Economy (Update 1)," Bloomberg, March 5.

Kennedy, Simon and Scott Lanman, 2010, "Bernanke, Trichet Economic Paths May Diverge at Jackson Hole," Bloomberg, August 27.

Kennedy, Simon and Stefan Riecher, 2013, "Draghi Cuts ECB Rates to Combat 'Prolonged' Inflation Weakness,' Bloomberg, November 7. 
Krugman, Paul, 2011, “An Impeccable Disaster,” The New York Times, September 11.

La Monica, Paul, 2007a, "Fed cuts rates to 4.5\%," CNN Money, November 1.

La Monica, Paul, 2007b, “Hope grows for a half-point cut,” CNN Money, December 5.

Kuehnen, Eva, 2011, "ECB surprises with rate cut, cautions on bond buys," Reuters, November 3.

Lander, Mark, 2008, “ECB raises key rate to 4.25\%," The New York Times, July 3.

Lanman, Scott and Craig Torres, 2008, "Fed Cuts Rate to as Low as Zero, Shifts Policy Focus (Update3)," Bloomberg, December 16.

Lanman, Scott, 2008, "Fed, ECB, Central Banks Cut Rates in Coordinated Move (Update 7)," Bloomberg, October 8.

Lawder, David, 2008, “Fed slashes rates,” Reuters, January 22.

Lawton, Christopher and Margit Feher, 2012, "ECB to Write History With Rate Cut But Will It Do More?" The Wall Street Journal, July 3.

Ljunggren, David and Lesley Wroughton, 2009, “G20 seals \$1.1 trillion deal, markets rally," Reuters, April 2.

Marsh, David, 2009, "France, Germany and Fissures in the Eurozone," Financial Times, January 11.

Mayer, Thomas, 2011, "Trichet must now raise rates again," The Financial Times, April 7.

McHugh, David, 2011, “ECB could cut benchmark rate," Yahoo News, December 8.

McHugh, David, 2012, "ECB cuts key rate to new low to help economy," Yahoo Finance, July 5.

Meier, Simone, 2007, "ECB May Raise Rate to 6-Year High, Signal More Moves (Update1)," Bloomberg, June 6.

Meier, Simone, 2009, "ECB Cuts Key Rate as Recession Forces Trichet's Hand (Update1)," Bloomberg, January 15.

Mody, Ashoka, 2014, "The ECB Can — and Must—Act," Bruegel, May 6, http://www.bruegel.org/nc/blog/detail/article/1323-the-ecb-must-and-can-act/. 
Mody, Ashoka, 2015, “Living dangerously without a Fiscal Union,” Bruegel Working Paper 2015/03, http://bruegel.org/wpcontent/uploads/imported/publications/WP_2015_03.pdf.

Mody, Ashoka and Guntram Wolff, 2015, "The Vulnerability of Europe's small and medium-sized Banks,” Bruegel Working Paper 2015/07, http://bruegel.org/wpcontent/uploads/imported/publications/WP 201507 160715-2 01.pdf.

Moore, Matt, 2007, “ECB Expected to Raise Key Interest Rate,” The Washington Post, March 8.

Nechio, Fernanda, 2011, "Monetary Policy When One Size Does Not Fit All," Federal Reserve Bank of San Francisco Economic Letter, June 13.

NPR, 2008a, "Fed Cuts a Key Rate in Bid to Lift Economy," April 30.

NPR, 2008b, "Fed Cuts Interest Rate By Half Point to 1 Percent,” October 29.

O'Brien, Matthew, 2014, "How the Fed Let the World Blow up in 2008," The Atlantic, February 26, http://www.theatlantic.com/business/archive/2014/02/how-the-fed-let-theworld-blow-up-in-2008/284054/.

Polidori, Elena, 2010, “Interview with Jean-Claude Trichet, President of the ECB, and La Repubblica," La Repubblica, June 10.

Randow, Jana, 2009, "ECB Cuts Rates to Record Low as Economy Sinks, Job Losses Mount," Bloomberg, March 5.

Randow, Jana and Simone Meier, 2009, “Trichet Indicates ECB May Cut Interest Rates Further (Update 3)," Bloomberg, March 5.

Randow, Jana and Jeff Black, 2013, "ECB Cuts Interest Rates to Record Low as Recession Lingers," Bloomberg, May 2.

Reuters, 2011, "Stocks Gain on Potential Jobs Improvement," The New York Times, July 7.

Rooney, Ben, 2009, “Dollar mixed in narrow range,” CNN Money, January 15.

Saltmarsh, Matthew, 2009, "European Bank Cuts Its Key Rate by a Quarter-Point," The New York Times, April 3.

Seager, Ashley, 2008, "Fed cuts interest rates by half a point," The Guardian, January 30.

Seager, Ashley and Kathryn Hopkins, 2008, "Another day of global market turmoil despite rate cut action," The Guardian, October 8. 
Shellock, Dave and Michael Mackenzie, 2008, "Overview: Global economy concerns weigh on markets," The Financial Times, February 11.

Shiller, Robert, 2015, "Fraud, Fools, and Financial Markets," Project Syndicate, September 17, https://www.project-syndicate.org/commentary/government-interventionfinancial-crises-by-robert-j--shiller-2015-09\#vzBX4410y7rb8gX3.99.

Shin, Hyun Song, 2012, "Global Bank Glut and the Loan Risk Premium," IMF Economic Review 60(2): 155-192.

Stark Jurgen, 2008, Monetary policy and the euro," Speech at the conference on "Advantages and benefits of the euro - time for assessment," European Economic and Social Committee, Brussels, April 15.

Stark, Jurgen, 2009, "EMU - Weathering the perfect storm," Speech delivered at the German-British Chamber of Industry \& Commerce London, June 25.

Stark, Jurgen, 2014, “The ECB's Leap into the Unknown,” Project Syndicate, October 1.

Steelman, Aaron, 2011, “The Federal Reserve's 'Dual Mandate': The Evolution of an Idea," The Federal Reserve Bank of Richmond Economic Brief, December 1.

Stubbington, Tommy and Christopher Whittall, 2015, "Euro Soars and Stocks Plunge as ECB Moves Dash Hopes; Stimulus measures fall well short of expectations," December 3.

Strupczewski, Jan, 2008, “ECB makes record rate cut,” Reuters, December 4.

Suoninen, Sakari, 2009, “ECB cuts rates by half-point,” Reuters, January 15.

Svensson, Lars, 1999, "Monetary policy issues for the Eurosystem," Carnegie-Rochester Conference Series on Public Policy 51: 79-136.

Svensson, Lars, 2002, "Sweden and the Euro," January, http://larseosvensson.se/files/papers/ep201.pdf.

Svensson, Lars, 1999, "Monetary Policy Issues for the Eurosystem," Carnegie-Rochester Conference Series on Public Policy 51: 79-136.

Svensson, Lars, 2011, "Practical Monetary Policy: Examples from Sweden and the United States,” Brookings Papers on Economic Activity Fall 2011: 289-352.

Svensson, Lars, 2013, "A comparison of monetary policy in Sweden with that in the Eurozone, the US, and the UK (English translation)," Ekonomistas, November 18. 
Taylor, John, 2010, “Globalization and Monetary Policy: Mission Impossible,” In International Dimensions of Monetary Policy, University of Chicago Press: 609-624.

Thesing, Gabi, 2009a, "ECB Cuts Rate Less Than Forecast as Recession Deepens," Bloomberg, April 2.

Thesing, Gabi, 2009b, "ECB Cuts Key Rate to Record Low, May Lengthen Loans (Update1)," Bloomberg, May 7.

Thesing, Gabi, 2011, "ECB Raises Key Interest Rate to $1.25 \%$ to Stem Faster Inflation," Bloomberg, April 7.

Thesing, Gabi and Jeff Black, 2011a, "Trichet Signals Further ECB Rate Increase," Bloomberg, July 7.

Thesing, Gabi and Jeff Black, 2011b, "ECB Cuts Key Rate to 1\%, May Dig Into Toolbox," Bloomberg, December 8.

Thesing, Gabi and Simone Meier, 2011, "Draghi Acts to Expand Credit to Banks, Doesn’t Signal More ECB Bond Buying," Bloomberg, December 8.

Thompson, Mark, 2013, "ECB: We're ready to fight a recession," CNN Money, May 2.

Thompson, Mark, 2014, "Europe steps up fight against deflation risk," CNN Money, June 5.

Tigges, Claus, 2007, “Zaubergriff statt ruhiger hand,” Frankfurter Allgemeine Zeitung, September 19.

Trichet, Jean-Claude and Lucas Papademos, 2007a, "Introductory statement with Q\&A," European Central Bank, April 12.

Trichet, Jean-Claude and Lucas Papademos, 2007b, "Introductory statement with Q\&A," European Central Bank, September 6.

Trichet, Jean-Claude and Lucas Papademos, 2007c, "Introductory statement with Q\&A," European Central Bank, October 4.

Trichet, Jean-Claude and Lucas Papademos, 2007d, "Introductory statement with Q\&A," European Central Bank, November 8.

Trichet, Jean-Claude and Lucas Papademos, 2007e, "Introductory statement with Q\&A," European Central Bank, December 6.

Trichet, Jean-Claude and Lucas Papademos, 2008a, "Introductory statement with Q\&A," European Central Bank, January 10. 
Trichet, Jean-Claude and Lucas Papademos, 2008b, "Introductory statement with Q\&A," European Central Bank, February 7.

Trichet, Jean-Claude and Lucas Papademos, 2008c, "Introductory statement with Q\&A," European Central Bank, April 10.

Trichet, Jean-Claude and Lucas Papademos, 2008d, "Introductory statement with Q\&A," European Central Bank, August 7.

Trichet, Jean-Claude and Lucas Papademos, 2008e, "Introductory statement with Q\&A," European Central Bank, September 4.

Trichet, Jean-Claude and Lucas Papademos, 2008f, "Introductory statement with Q\&A," European Central Bank, December 4.

Trichet, Jean-Claude and Lucas Papademos, 2009a, "Introductory statement with Q\&A," European Central Bank, January 15.

Trichet, Jean-Claude and Lucas Papademos, 2009b, "Introductory statement with Q\&A," European Central Bank, March 5.

Trichet, Jean-Claude and Vítor Constâncio, 2011a, "Introductory statement to the press conference (with Q\&A)," European Central Bank, January 13.

Trichet, Jean-Claude and Vítor Constâncio, 2011b, "Introductory statement to the press conference (with Q\&A), " European Central Bank, March 3.

Trichet, Jean-Claude and Vítor Constâncio, 2011c, "Introductory statement to the press conference (with Q\&A)," European Central Bank, April 7.

Trichet, Jean-Claude and Vítor Constâncio, 2011d, "Introductory statement to the press conference (with Q\&A)," European Central Bank, June 9.

Trichet, Jean-Claude and Vítor Constâncio, 2011e, "Introductory statement to the press conference (with Q\&A)," European Central Bank, July 7.

Trichet, Jean-Claude and Vítor Constâncio, 2011f, "Introductory statement to the press conference (with Q\&A)," European Central Bank, September 8.

Trotta, Daniel, 2008, "Europe cuts rates as Obama to address global crisis," Reuters, November 6.

Ubide, Ángel, 2008, “Decisión histórica,”El País, December 17. 
Uchitelle, Louis, 2007, “Fed Cuts Rate a Quarter Point; Stocks Dive,” The New York Times, December 11.

Vits, Christian, 2008, "ECB Cuts Interest Rate by Half Point to Counter Economic Slump," Bloomberg, November 6.

Watts, William, 2008, “ECB hikes key rate to 4.25\%," MarketWatch, July 3.

Wiesmann, Gerrit, 2008, "Eurozone inflation soars to new high,” The Financial Times, June 30 .

Wilson, James, 2012, “ECB cuts interest rates to historic low,” The Financial Times, July 5 .

Wolff, Guntram, 2014, "The ECB Should be More Aggressive with Monetary Policy, http://bruegel.org/2014/03/the-ecb-should-be-more-aggressive-on-monetary-policy/.

Woodford, Michael, 2012, "Methods of Policy Accommodation at the Interest-Rate Lower Bound," September 16, https://www.kansascityfed.org/publicat/sympos/2012/mw.pdf.

Ydstie, John, 2008, “Will the Fed's Latest Rate Cut Help the Economy?" NPR, October 29.

Zhou, Wanfeng, 2007, “Euro edges lower after ECB rate move," MarketWatch, June 6. 